\title{
Sensitivities in global scale modeling of isoprene
}

\author{
R. von Kuhlmann ${ }^{1}$, M. G. Lawrence ${ }^{1}$, U. Pöschl ${ }^{2}$, and P. J. Crutzen ${ }^{1,3}$ \\ ${ }^{1}$ Max-Planck-Institut für Chemie, Postfach 3060, 55020 Mainz, Germany \\ ${ }^{2}$ Institut für Wasserchemie, Technische Universität München, München, Germany \\ ${ }^{3}$ Scripps Institution of Oceanography, UC San Diego, La Jolla, CA, USA
}

Received: 22 April 2003 - Published in Atmos. Chem. Phys. Discuss.: 18 June 2003

Revised: 27 November 2003 - Accepted: 23 December 2003 - Published: 20 January 2004

\begin{abstract}
A sensitivity study of the treatment of isoprene and related parameters in 3D atmospheric models was conducted using the global model of tropospheric chemistry MATCH-MPIC. A total of twelve sensitivity scenarios which can be grouped into four thematic categories were performed. These four categories consist of simulations with different chemical mechanisms, different assumptions concerning the deposition characteristics of intermediate products, assumptions concerning the nitrates from the oxidation of isoprene and variations of the source strengths. The largest differences in ozone compared to the reference simulation occured when a different isoprene oxidation scheme was used (up to $30-60 \%$ or about $10 \mathrm{nmol} / \mathrm{mol}$ ). The largest differences in the abundance of peroxyacetylnitrate (PAN) were found when the isoprene emission strength was reduced by $50 \%$ and in tests with increased or decreased efficiency of the deposition of intermediates. The deposition assumptions were also found to have a significant effect on the upper tropospheric $\mathrm{HO}_{\mathrm{x}}$ production. Different implicit assumptions about the loss of intermediate products were identified as a major reason for the deviations among the tested isoprene oxidation schemes. The total tropospheric burden of $\mathrm{O}_{3}$ calculated in the sensitivity runs is increased compared to the background methane chemistry by $26 \pm 9 \mathrm{Tg}\left(\mathrm{O}_{3}\right)$ from 273 to an average from the sensitivity runs of $299 \mathrm{Tg}\left(\mathrm{O}_{3}\right)$. Thus, there is a spread of $\pm 35 \%$ of the overall effect of isoprene in the model among the tested scenarios. This range of uncertainty and the much larger local deviations found in the test runs suggest that the treatment of isoprene in global models can only be seen as a first order estimate at present, and points towards specific processes in need of focused future work.
\end{abstract}

Correspondence to: R. von Kuhlmann

(kuhlmann@mpch-mainz.mpg.de)

\section{Introduction}

The chemistry of non-methane volatile organic compounds (NMVOC) is known to significantly affect the formation of ozone in large parts of the atmosphere and can strongly influence the abundance of hydroxyl radical $(\mathrm{OH})$ concentrations (Houweling et al., 1998; Wang et al., 1998; Poisson et al., 2000). However, little work has been made to assess the uncertainties associated with current model predictions of these effects.

Isoprene is among the most important NMVOC species in the atmosphere with estimated emissions of about 500 $\mathrm{Tg}(\mathrm{C}) / \mathrm{yr}$ amounting almost one half of the global total biogenic emission strength of $1150 \mathrm{Tg}(\mathrm{C}) / \mathrm{yr}$ (Guenther et al., 1995). Even in some industrialized regions its emissions can be comparable to anthropogenic hydrocarbon emissions (Lamb et al., 1993). An increasing importance of isoprene in the future has been hypothesised by Shallcross and Monks (2000) due to increasing net primary productivity in a warmer climate. Recently, Sanderson et al. (2003) have calculated increasing emissions from $549 \mathrm{Tg}(\mathrm{C}) / \mathrm{yr}(1990 \mathrm{~s})$ to $697 \mathrm{Tg}(\mathrm{C}) / \mathrm{yr}$ in the 2090s including natural vegetation changes. Changes in land use due to anthropogenic activity can be another influential factor.

On the other hand Rosenstiel et al. (2003) recently found that isoprene emissions from an agriforest plantation decreased under increased $\mathrm{CO}_{2}$ exposure.

The oxidation of NMVOCs in the atmosphere can involve hundreds of species and thousands of reactions (Madronich and Calvert, 1989; Poisson, 1997; Saunders et al., 1997). In addition to the incomplete knowledge about some details of these degradation sequences an uncertainty is therefore introduced through their representation by simplified reaction schemes suitable for three-dimensional chemistrymeteorology applications.

Traditionally, these uncertainties are assessed in boxmodel studies by comparing a complex reaction scheme with 
Table 1. Isoprene related species in the MIM.

\begin{tabular}{|c|c|c|}
\hline No. & Name & Description \\
\hline 1 & $\mathrm{C}_{5} \mathrm{H}_{8}$ & isoprene \\
\hline 2 & $\mathrm{ISO}_{2}$ & peroxy radicals from $\mathrm{C}_{5} \mathrm{H}_{8}+\mathrm{OH}$ \\
\hline 3 & ISOOH & $\beta$-hydroxyhydroperoxides from $\mathrm{ISO}_{2}+\mathrm{HO}_{2}$ \\
\hline 4 & ISON & $\begin{array}{l}\beta \text {-hydroxyalkylnitrates from } \mathrm{ISO}_{2}+\mathrm{NO} \text { and } \\
\text { alylnitrates from } \mathrm{C}_{5} \mathrm{H}_{8}+\mathrm{NO}_{3}\end{array}$ \\
\hline 5 & MACR & $\begin{array}{l}\text { methacrolein, methylvinylketone and other } \mathrm{C}_{4} \\
\text { carbonyls }\end{array}$ \\
\hline 6 & $\mathrm{MACRO}_{2}$ & peroxy radicals from MACR $+\mathrm{OH}$ \\
\hline 7 & MACROOH & hydroperoxides from $\mathrm{MACRO}_{2}+\mathrm{HO}_{2}$ \\
\hline 8 & MPAN & $\begin{array}{l}\text { peroxymethacryloylnitrate and other higher } \\
\text { peroxyacylnitrates }\end{array}$ \\
\hline 9 & HACET & hydroxyacetone and other $\mathrm{C}_{3}$ ketones \\
\hline 10 & MGLY & methylglyoxal and other $\mathrm{C}_{3}$ aldehydes \\
\hline 11 & $\mathrm{CH}_{3} \mathrm{O}_{3}$ & peroxyacetyl radical \\
\hline 12 & PAN & peroxyacetylnitrate \\
\hline 13 & $\mathrm{CH}_{3} \mathrm{O}_{3} \mathrm{H}$ & peroxyacetic acid \\
\hline 14 & $\mathrm{CH}_{2} \mathrm{OOH}$ & acetic acid \\
\hline 15 & NALD & nitrooxyacetaldehyde \\
\hline 16 & $\mathrm{HCOOH}$ & formic acid \\
\hline
\end{tabular}

a simplified mechanism under different typical atmospheric conditions (e.g. Pöschl et al., 2000; Liang and Jacobson, 2000; Geiger et al., 2003). Comparison to smog chamber results are also performed, but currently they do not cover low- $\mathrm{NO}_{\mathrm{x}}$ conditions encountered in remote clean environments. However, box-model studies cannot fully account for the complex non-linear interaction between chemical and physical processes such as mixing, transport or deposition occurring in the atmosphere. Thus, an overarching view of the uncertainties connected to the chemical and physical properties of the NMVOC species is only possible with a 3D chemistry-transport model (CTM). On the other hand, the number of uncertain parameters becomes even larger in the 3D framework which make a subjective selection of test cases necessary.

In a box model study Pöschl et al. (2000) compared one detailed and five condensed isoprene oxidation mechanisms with each other under various scenarios relevant to the atmosphere. The Mainz Isoprene Mechanism (MIM) developed in that study was designed to be in relatively close agreement to a detailed mechanism, the Master Chemical Mechanism (MCM, Jenkin et al., 1997; Saunders et al., 1997). However, large deviations were found between the other mechanisms, both relative to each other and to the MCM.

In this study we perform a sensitivity analysis of factors connected to modeling the effects of isoprene emissions using a 3D CTM. This can be seen as an expansion upon the work of Pöschl et al. (2000) in two ways. Firstly, selected condensed isoprene mechanisms also compared in that study have been implemented in the 3D model allowing to investi- gate whether the effects found in the box model study are also relevant in the 3D context. Secondly, the global 3D model also allows the influence of non-chemical loss processes on the calculated results to be examined.

It is, however, not possible in the 3D model to directly assess the uncertainties in the explicit formulation of isoprene oxidation and thus our selection of three condensed isoprene oxidation schemes can be seen as a pragmatic way to get indications on the overall spread in global 3D simulations of isoprene chemistry. Also, sensitivity to the meteorological representations in the model will not be investigated in this study. Especially vertical mixing processes (boundary layer turbulence and convection) could significantly affect the long-range effects of isoprene and would be a valuable research task which, however, goes beyond the scope of this study.

In the next section a short overview of the 3D global model MATCH-MPIC used for this study is given and the setup of the sensitivity simulations is outlined. In Sect. 4 the selected sensitivity scenarios are described and motivated. The scenarios fall in four groups covering assumption about the chemical scheme, emission strengths, the fate of isoprene nitrates and deposition of intermediates. In Sects. 5 to 8 the results from each of these groups is presented and discussed. A summary of the discussions and results is then given in Sect. 9.

\section{Model setup}

We use the global tropospheric chemistry model MATCHMPIC (Model of Atmospheric Transport and Chemistry Max-Planck-Institute for Chemistry version) in this sensitivity study. The model has been under development over several years (Rasch et al., 1997; Mahowald et al., 1997b,a; Lawrence et al., 1999). The most recent version which includes the chemistry of non-methane hydrocarbons using a flexible set-up is presented in von Kuhlmann et al. (2003a) and it is also used to make chemical forcasts to aid in campaign flight planning (Lawrence et al., 2003).

The model is driven by 6-hourly basic meteorological parameters (u,v-wind, latent and sensible heat flux, specific humidity, surface pressure, surface stress components) from NCEP (Kalnay et al., 1996). The sensitivity simulations are done at a resolution of about 5.6 $\times 5.6^{\circ}$ (T21 Gaussian grid) based on additional parameter fields which have been archived from a higher resolution $\left(\mathrm{T} 63\right.$ or $\left.1.9^{\circ} \times 1.9^{\circ}\right)$ run ("archived mode") (see Rasch et al., 1997).

The model applies industrial emissions from the EDGAR database Version 2.0 (Olivier et al., 1996), biomass burning from Galanter et al. (2000), soil- $\mathrm{NO}_{\mathrm{x}}$ emission from Yienger and Levy (1995). Lightning- $\mathrm{NO}_{\mathrm{x}}$ is parameterized based on Price and Rind (1994) with a global emission strength of 5 $\mathrm{Tg}-\mathrm{N} / \mathrm{yr}$. Biogenic isoprene emissions are based on monthly mean values from Guenther et al. (1995), but have been 
Table 2. Comparison of observed isoprene mixing ratios (in $\mathrm{nmol} / \mathrm{mol}$ ) with model calculations for the high resolution run (T63) and at the reduced resolution (T21). 24-hour means are marked with " $24 \mathrm{~h}$ ", otherwise daytime values are reported. Model values are monthly (24 hour) averages. In brackets maximum and minimum of single measurements.

\begin{tabular}{lcllclll}
\hline Location & Time & Lat. & Lon. & Observations & T63 & T21 & Reference \\
\hline Canada, Egbert & July & 44 & -79 & 0.5 & 0.3 & 0.4 & Bottenheim and Shepherd (1995) \\
, Kejimkujik & July & 45 & -65 & 2.0 & 0.2 & 0.3 & Bottenheim and Shepherd (1995) \\
, Fraserdale & Jul.-Aug. & 50 & -82 & $0.5-5$ & 0.5 & 0.4 & Jobson et al. (1994) \\
Niwot Ridge & Aug.-Sept. & 40 & -105 & $0.6(0.2-1.8)$ & 0.2 & 0.1 & Greenberg and Zimmerman (1984) \\
& Nov. & 40 & -105 & $0.1(0.03-0.2)$ & 0.04 & 0.04 & Greenberg and Zimmerman (1984) \\
Georgian Rep. & Summer & 42 & 43 & $1.4($ max. 6) & 0.2 & 0.2 & Shaw et al. (1983) \\
Japan & July, 24h & 38 & 140 & 0.3 & 0.2 & 0.1 & Yokouchi (1994) \\
& Nov, 24h & 38 & 140 & 0.2 & 0.02 & 0.01 & Yokouchi (1994) \\
Alabama & Jun.-Jul., 24h & 32 & -88 & $3.8(1-7)$ & 2.9 & 2.4 & Montzka et al. (1993) \\
Amazonia & Jul. & 2 & -60 & $2.2(1.2-3.2)$ & 6.7 & 11.0 & Rasmussen and Khalil (1988) \\
Amazonia & year-round & 2 & -60 & $2.4(1.0-5.2)$ & 6.1 & 9.0 & Greenberg and Zimmerman (1984) \\
Amazonia & Jul.-Aug. & -2 & -60 & $2(1.1-2.7)$ & 6.4 & 14.5 & Zimmerman et al. (1988) \\
Peru & July & -5 & -77 & 3.3 & 10.3 & 15.6 & Helmig et al. (1998) \\
Venezuela, Buja & Sept. & 9 & -62 & 3.3 & 3.8 & 3.0 & Donoso et al. (1996) \\
, Auyantepuy & Apr., 24h & 6 & -62 & 1.6 & 1.9 & 3.1 & Donoso et al. (1996) \\
, Calabozo & Sep.-Oct.,24h & 9 & -67 & $0.8(0.2-3.1)$ & 5.9 & 7.8 & Holzinger et al. (2002) \\
, Calabozo & Mar.-Apr.,24h & 9 & -67 & $0.5(0.1-1)$ & 0.5 & 0.5 & Holzinger et al. (2002) \\
, Parupa & Jan.-Feb. & 6 & -62 & $0.5(0.1-1.2)$ & 1.2 & 2.3 & Holzinger et al. (2002) \\
Surinam (PBL) & Mar. & $2-7$ & $-54-58$ & $3.5(0.5-7)$ & 2.8 & 2.5 & Warneke et al. (2001) \\
\hline
\end{tabular}

reduced to a global emission strength of $350 \mathrm{Tg}-\mathrm{C} / \mathrm{yr}$. A diurnal cycle is imposed by scaling to the cosine of the solar zenith angle with zero emissions during night. Dry deposition is based on a resistance model (Ganzeveld and Lelieveld, 1995) using parameterizations of surface resistances from Wesely (1989) based on the Henry's Law constants of each species. Wet deposition is also parameterized based on the solubilities and assuming equilibrium between gas and aqueous phase (see Crutzen and Lawrence, 2000).

A short discussion stressing the most relevant points of the evaluation of the model using the full NMVOC scheme is given in the next section.

In all simulations only the "background" $\mathrm{CH}_{4}-\mathrm{CO}-\mathrm{NO}_{\mathrm{x}}-$ $\mathrm{HO}_{\mathrm{x}}$ chemistry system and isoprene chemistry is included. A list of isoprene related species in our standard isoprene oxidation mechanism MIM (Pöschl et al., 2000) is given in Table 1. Other non-methane hydrocarbons have been omitted in these runs in order to focus the tests explicitly on isoprene. It has been shown by Wang et al. (1998) that isoprene alone is responsible for a large fraction of the overall effects of all NMVOCs, especially in the tropics on which we focus here. Thus, the sensitivity runs are usefull to identify the most uncertain points in treating isoprene in global models. However, it must be realized that anthropogenic VOC neglected would affect the sensitivities in the polluted northern extratropics. Moreover the highly uncertain emissions of other biogenic NMVOC emission (e.g. terpenes, sesquiterpenes) neglected in this study could affect the calculated sensitivities. For reference the changes found in the different test cases will also be compared with the overall effect of adding isoprene chemistry to the background chemistry.
All simulations start on 2 March 1998, from a well spunup model state. Only the monthly mean results for May are analyzed here. Thus, an additional spin-up period of 2 months is allowed for each simulation. The month May has been chosen because it is characterized by frequent rainfall over large parts of the tropical continents south of the ITCZ (wet season). During this season very little burning activity is occurring and thus the $\mathrm{NO}_{\mathrm{x}}$ concentrations are relatively low (Jacob and Wofsy, 1990). Under these conditions isoprene chemistry is expected to be most uncertain, since the mechanisms are only tested with smog chamber data with $\mathrm{NO}_{\mathrm{x}}$ concentrations in the hundred $\mathrm{nmol} / \mathrm{mol}$ to $\mathrm{mmol} / \mathrm{mol}$ range (e.g. Zaveri and Peters, 1999).

The discussion will focus on the effects in the tropics and especially over the Amazon rain forest, although global budget information is also presented from each run to show the global mean effect. It is noted, however, that the effects of isoprene and its uncertainties are probably not very large in May in the northern extra-tropics, since isoprene emissions maximize 2-3 months later.

\section{Model performance}

The model results of the full version (including other NMVOCs) have been extensively evaluated with ozone observations in von Kuhlmann et al. (2003a), and the comparison with a large suite of observations of ozone precursors $\left(\mathrm{CO}, \mathrm{NO}_{x}, \mathrm{NMVOCs}\right.$, oxygenates etc.) is resented in von Kuhlmann et al. (2003b). Since not all comparisons (which are also posted at http://www.mpch-mainz.mpg.de/ 
Table 3. Short descriptions and acronyms of the sensitivity simulations discussed in this section.

\begin{tabular}{|c|c|}
\hline Case name & Description \\
\hline $\mathrm{CH} 4$ & Only backgound $\mathrm{CH}_{4}-\mathrm{CO}-\mathrm{NO}_{\mathrm{X}}-\mathrm{HO}_{\mathrm{x}}$ chemistry. \\
\hline BASE & Base run with background and isoprene chemistry (no other NMVOCs). \\
\hline MOZART & Isoprene chemistry from the MOZART model (Brasseur et al., 1998). \\
\hline \multirow[t]{2}{*}{$\mathrm{CBM}$} & Isoprene chemistry of the modified CBM-IV mechanism by \\
\hline & Houweling et al. (1998). \\
\hline LOWISOP & Isoprene emissions reduced by $50 \%$ in the tropics $\left(20^{\circ} \mathrm{S}-20^{\circ} \mathrm{N}\right)$. \\
\hline LOWSOIL & $\begin{array}{l}\text { Soil- } \mathrm{NO}_{\mathrm{X}} \text { emissions reduced by } 50 \% \text { over forested areas in the tropics } \\
\left(20^{\circ} \mathrm{S}-20^{\circ} \mathrm{N}\right) \text {. }\end{array}$ \\
\hline LOWLTNG & $\begin{array}{l}\text { Production of NO from lightning reduced by } 60 \% \text { over the continental tropicial } \\
\text { South America. }\end{array}$ \\
\hline HIGHISON & Doubled yield of isoprene nitrates from the $\mathrm{ISO}_{2}+\mathrm{NO}$ reaction. \\
\hline INHNO3 & Production of isoprene nitrates is channeled into $\mathrm{HNO}_{3}$. \\
\hline NONACA & $\begin{array}{l}\text { Reaction products of the oxidation of the isoprene nitrates with } \mathrm{OH} \text { are } \\
\text { assumed to be lost from the atmosphere (thus product NACA is omitted). }\end{array}$ \\
\hline LOWDEP & $\begin{array}{l}\text { Deposition properties (dry+wet) of hydroxy-hydroperoxides from } \\
\text { isoprene assumed to be the same as for } \mathrm{CH}_{3} \mathrm{OOH} \text {. }\end{array}$ \\
\hline VLOWDEP & Deposition of all intermediates of isoprene oxidation switched off. \\
\hline HIGHDEP & $\begin{array}{l}\text { Assumed loss of } 70 \% \text { of hydroxy-hydroperoxides from isoprene } \\
\text { (as in Brasseur et al., 1998). }\end{array}$ \\
\hline
\end{tabular}

$\sim$ kuhlmann/matcheval) could be discussed in those studies, we provide some additional discussions in this section, focusing on species (isoprene, $\mathrm{NO}_{y}$-species) and regions (tropics, rainforest) that would have the strongest influence on our sensitivity simulations with different chemical schemes and can serve as motivation for the sensitivity runs with different emissions described in the next section. These can also help to judge if the changes introduced in those runs would improve or deteriorate the comparison.

For reference the surface distribution of isoprene from the BASE simulation in May is shown in Fig. 1 together with the calculated distribution of $\mathrm{NO}_{\mathrm{x}}$ in the boundary layer. Comparison of measurements of isoprene at single locations must be seen with caution due to the coarse model grid and small scale horizontal variations in its concentration. Nevertheless, the ensemble of model/measurement comparisons can give indications about general tendencies of the model to over or under-predict concentrations in certain ecosystems. A compilation of available surface measurements along with model predictions is listed in Table 2.

The model appears to be in agreement with measurements made in North America. Measurements in Japan are expected to be underestimated, since also low emission over oceans from the original $1^{\circ} \times 1^{\circ}$ emission data are averaged into the coarse model grid-cell, resulting in lower average fluxes at this location.

The model significantly overestimates mixing ratios found in the central Amazon region, sometimes by a factor of 3 . The sites are probably quite representative of the region, since no major inhomogeneities in the vegetation are expected. This may not be the case for the Peru site which is located in a region where a strong horizontal gradient in isoprene is calculated within a few grid cells of the model. The value of the nearest grid cell to the east representative of the rainforest ecosystem is used for this station; using an interpolation to the exact measurement location would also overestimate the observations.

This overestimate is consistent with findings in other 3D global model studies (Houweling et al., 1998; Granier et al., 2000). Besides too high emissions of the rainforest ecosystem as also suggested by Rinne et al. (2002) other factors such as too weak vertical mixing or unknown deposition processes (Holzinger et al., 2002) could contribute to the overestimate. In fact, over Surinam the model predicts a too strong decrease of isoprene with altitude compared to the measurements by Warneke et al. (2001) which indicate efficient mixing by shallow convection up to $4 \mathrm{~km}$.

Measurements of $\mathrm{NO}_{\mathrm{y}}$ species over the tropical rainforest are very scarce. The model somewhat overestimates the tower measurements from the ABLE-2A campaign over the central Amazon in May (Bakwin et al., 1990) (mean 450 $\mathrm{pmol} / \mathrm{mol}$ observed, $700 \mathrm{pmol} / \mathrm{mol}$ calculated), but the model is within the central $67 \%$ of the data. The model also appears to be on the high side of aircraft measurements of NO from the same campaign (Torres and Buchan, 1988), but here the diurnal cycle of NO complicates the comparison. A model daytime average value is calculated from the $24 \mathrm{~h}-$ mean output data assuming zero NO during nighttime. When excluding data from early morning measurements to get a more representative daytime value of NO (see Müller and Brasseur, $1995)$ the model is consistent with observations. 

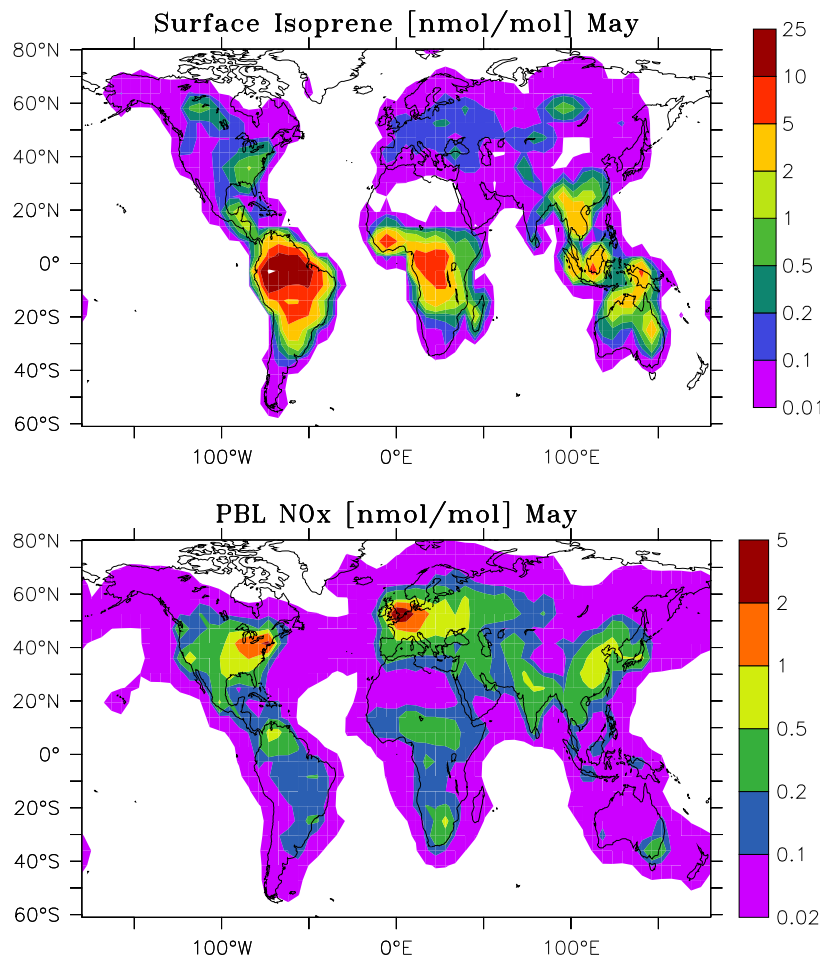

Fig. 1. Distribution of surface isoprene and boundary layer $\mathrm{NO}_{\mathrm{x}}$ $\left(p / p_{\text {surf }}<0.8\right)$ in the BASE run.

A tendency of the model to overestimate PAN mixing ratios in the remote upper troposphere was identified in von Kuhlmann et al. (2003b). This is also the case for the airborne PAN measurements during ABLE-2A (Singh et al., 1990) which are about a factor of 2 lower than calculated in the model. The exact reason for this is unknown, but it was found that a change in the thermal equilibrium constants of PAN did not mitigate the problem. Another possible reason is checked in a sensitivity run which employs a reduced $\mathrm{NO}_{\mathrm{x}}$ production from lightning in the Amazon region.

\section{Description of the sensitivity runs}

A total of 13 sensitivity simulations have been performed, including a BASE simulation and a simulation only including the background chemistry (denoted CH4). An acronym for each run and a short description is given in Table 3. Most of the modified assumption in these runs can be considered to be within the range of uncertainties of our current knowledge or have been used in the recent literature. Not all tests are equally relevant and some simulations are therefore only discussed briefly. The sensitivity simulations in Table 3 can be subdivided into four groups, which are discussed separately in the following four subsections.

\subsection{Chemical schemes}

The first group consists of three simulations (including the base run) with different condensed isoprene mechanisms. The Mainz Isoprene Mechanism (MIM) (Pöschl et al., 2000) is compared to two other mechanisms used in global modeling studies (CBM, Houweling et al. (1998) and MOZART, Brasseur et al. (1998)). These two mechanisms have been implemented in MATCH-MPIC using the flexible integration technique as described in von Kuhlmann et al. (2003a). In order to focus on mechanistic differences in the isoprene oxidation scheme, the rate parameters for the initial reactions of isoprene with $\mathrm{OH}, \mathrm{O}_{3}$ and $\mathrm{NO}_{3}$, and also for the PAN chemistry have been harmonized for all three mechanisms. The same photolysis rates are also used for reactions common to the three mechanisms. Other rates within each isoprene oxidation scheme are used as in the original publications, though it should be noted that the full implemention will be slightly different from the originals due to our harmonization of the PAN chemistry. The isoprene chemistry of the MIM used in the BASE simulation contains about 45 isoprene related reactions and 16 species in addition to the background methane chemistry (see Table 1). Each stage of the degradation is represented by a few species so that the reaction pathways prevailing under low and high $\mathrm{NO}_{\mathrm{x}}$ conditions can be adequately represented by the surrogate species. Hydroxyhydroperoxides from isoprene (ISOOH and MACROOH), which are assumed to form in $\mathrm{NO}_{\mathrm{x}}$-bereft environments are explicitly treated in the scheme. These compounds have been tentatively identified over the rainforest in Surinam (Crutzen et al., 2000; Warneke et al., 2001) and over the savanna in Venezuela (Holzinger et al., 2002).

The mechanism (mainly based on Müller and Brasseur, 1995) used in the global chemistry-transport model MOZART (Brasseur et al., 1998) is similar in complexity to the MIM (about 19 species and 50 reactions). The main differences are the neglected treatment of hydroxyhydroperoxides. Instead, $70 \%$ of these compounds are assumed to be lost through heterogeneous processes and the remainder is immediately oxidized to smaller products. The main $\mathrm{C}_{4}$-products of the oxidation of isoprene, methylvinylketone (MVK) and methacrolein (MACR) are treated separately, as opposed to the method of lumping them into a single compound in the MIM. The hypothetical reactions of MVK, MACR and methylglyoxal with sulfate aerosols assumed in Brasseur et al. (1996) are not included in the implementation in MATCH-MPIC.

Another difference is the relatively low reactivity assumed for the isoprene nitrates in the MOZART scheme, which may be used because isoprene nitrates are lumped together with other less reactive alkyl nitrates. The reaction rate with $\mathrm{OH}$ used in MOZART is $6.8 \cdot 10^{-13} \mathrm{molec} / \mathrm{cm}^{3} / \mathrm{s}$ compared to 1.3 $\cdot 10^{-11}$ in the MIM. The latter value has been estimated using the structure-reactivity relationship (SAR) method of Kwok and Atkinson (1995). However, it is noted that this method 
not very reliable for organic nitrates (Neeb, 2000) and the reactivity of these nitrates must be seen as another uncertainty in the oxidation of isoprene.

A very simple oxidation scheme of isoprene (about 12 species or operators and 30 reactions) has been constructed by Houweling et al. (1998), based on the CBM-IV mechanism of Gery et al. (1989). The lumping approach used in the CBM-IV to reduce the complexity of the degradation schemes of higher hydrocarbons is different than used in the MIM or the MOZART scheme. A structural lumping, which groups species according to their bond type is used, as opposed to molecular lumping in MIM and MOZART, where groups of reactions of entire molecules are combined. The initial reaction of isoprene with $\mathrm{OH}$ in the $\mathrm{CBM}$ mechanism of Houweling et al. (1998) is:

$$
\begin{aligned}
\mathrm{C}_{5} \mathrm{H}_{8} & +\mathrm{OH} \rightarrow 0.85 \mathrm{XO} 2+0.61 \mathrm{HCHO}+0.85 \mathrm{HO}_{2} \\
& +0.03 \mathrm{MGLY}+0.58 \mathrm{OLE}+0.15 \mathrm{XO} 2 \mathrm{~N}+0.63 \mathrm{PAR} .
\end{aligned}
$$

Here, $\mathrm{XO} 2$ and $\mathrm{XO} 2 \mathrm{~N}$ are peroxy-radical operators and OLE and PAR denote olefinic and paraffinic carbon bonds. It is noted that upon this first reaction about $50 \%$ of the carbon is lost and replaced by carbon-free operators.

It has to be kept in mind that "PAN" in this scheme denotes all PAN-type species which makes this quantity not strictly comparable to the PAN in the other schemes. However, other PANs from isoprene chemistry are more reactive than PAN and will thus hardly contribute to long-range transport of $\mathrm{NO}_{\mathrm{x}}$ to remote regions. From the contribution of MPAN to total PAN one can estimate that this difference is negligible in remote regions and that other PAN species could contribute about $10 \%$ to $30 \%$ in the upper troposphere and near the surface, respectively.

\subsection{Emission strengths}

In this group of simulations some relevant emission strengths are varied. The decision for an increase or decrease of the emissions strengths has been based on the findings from the model evaluation in von Kuhlmann et al. (2003b) so as to give better agreement with observations.

Due to the finding in Sect. 3 of an overestimate of isoprene over the Amazon with the standard global isoprene emission strength of $350 \mathrm{Tg}(\mathrm{C}) / \mathrm{yr}$ a test simulation (LOWISOP) with isoprene emissions reduced by $50 \%$ in the tropics was made, resulting in a global emission strength of about $215 \mathrm{Tg}(\mathrm{C}) / \mathrm{yr}$. The figure is comparable to the value of $220 \mathrm{Tg}(\mathrm{C}) / \mathrm{yr}$ used by Brasseur et al. (1998).

Soil emissions and lightning are the most important $\mathrm{NO}_{\mathrm{x}}$ emissions in tropical ecosystems in the wet season when biomass burning activity is low. A critical issue in determining the actual flux of nitrogen into the atmosphere is recapture of nitrogen containing compounds within the canopy (e.g. Ganzeveld et al., 2002).
In the soil emission data set of Yienger and Levy (1995) applied in MATCH-MPIC this is taken into account by simple mechanistic assumptions. For tropical rain forest the canopy reduction factor, which expresses the fraction of nitrogen that is actually exported from the canopy, is given in Yienger and Levy (1995) as 0.25. In the LOWSOIL test simulation it was assumed that the soil emission over forested regions of the tropics is $50 \%$ smaller. This would correspond to a canopy reduction factor of about 0.13 , or a $50 \%$ reduced primary soil emission strength with an unchanged reduction factor. The reduced emissions would bring $\mathrm{NO}_{\mathrm{y}}$ surface concentrations in better agreement with observations. The change in the global source strength of NO, however, was found to be only about $5 \%$ (or $0.3 \mathrm{Tg}(\mathrm{N}) / \mathrm{yr}$ ), because tropical forest soils during the wet season are not very productive and most soil NO is released to the atmosphere over less forested regions (e.g. savanna).

The production by lightning is calculated to be an even larger source of NO to the Amazon region in MATCH-MPIC (vertically integrated). In a comparison to the GOME column $\mathrm{NO}_{2}$ data of Richter and Burrows (2002) it is found that this source is probably overestimated in MATCH-MPIC over this region during the wet season (see von Kuhlmann, 2001), in line with the overstimate of PAN over the region in Sect. 3. In another sensitivity run (LOWLTNG) therefore the NO production from lightning has been reduced by $60 \%$ over this region (continental South America, north of about $\left.15^{\circ} \mathrm{S}\right)$. This reduction applied globally would result in a total source strength of $2 \mathrm{Tg}(\mathrm{N}) / \mathrm{yr}$ in MATCH, which is near the low end of current estimates (e.g. Lawrence et al., 1995). Due to the regional restriction of the reduction the global source strength is only reduced by $0.6 \operatorname{Tg}(\mathrm{N}) / \mathrm{yr}$ or $13 \%$ in May (from 4.8 to $4.2 \operatorname{Tg}(\mathrm{N}) / \mathrm{yr}$ ).

\subsection{Isoprene nitrates}

Since Pöschl et al. (2000) pointed out that the different treatment of organic nitrates formed in the course of isoprene oxidation were responsible for a large part of the differences seen in box model simulations with various isoprene oxidation schemes, some tests were also performed to explore their role in the 3D model. In the HIGHISON simulation a doubled yield of isoprene nitrates (denoted ISON in the MIM) is used. The value of $8.8 \%$ corresponds to the best estimate of Carter and Atkinson (1996), which is, however, in disagreement with the value of $4.4 \%$ obtained by Chen et al. (1998) and used in all other runs here. Recently, a higher yield of 8$12 \%$ supporting the previous results of Carter and Atkinson (1996) was inferred by Sprengnether et al. (2002).

Uncertainties also exists in the fate of these nitrates. In most reduced mechanisms, including the three tested here, two different groups of nitrates are represented by a single compound: The products of the reaction of isoprene with $\mathrm{NO}_{3}$ and the group of $\beta$-hydroxy-nitrates from the peroxy radicals which are formed from the $\mathrm{C}_{5} \mathrm{H}_{8}+\mathrm{OH}$ reaction 

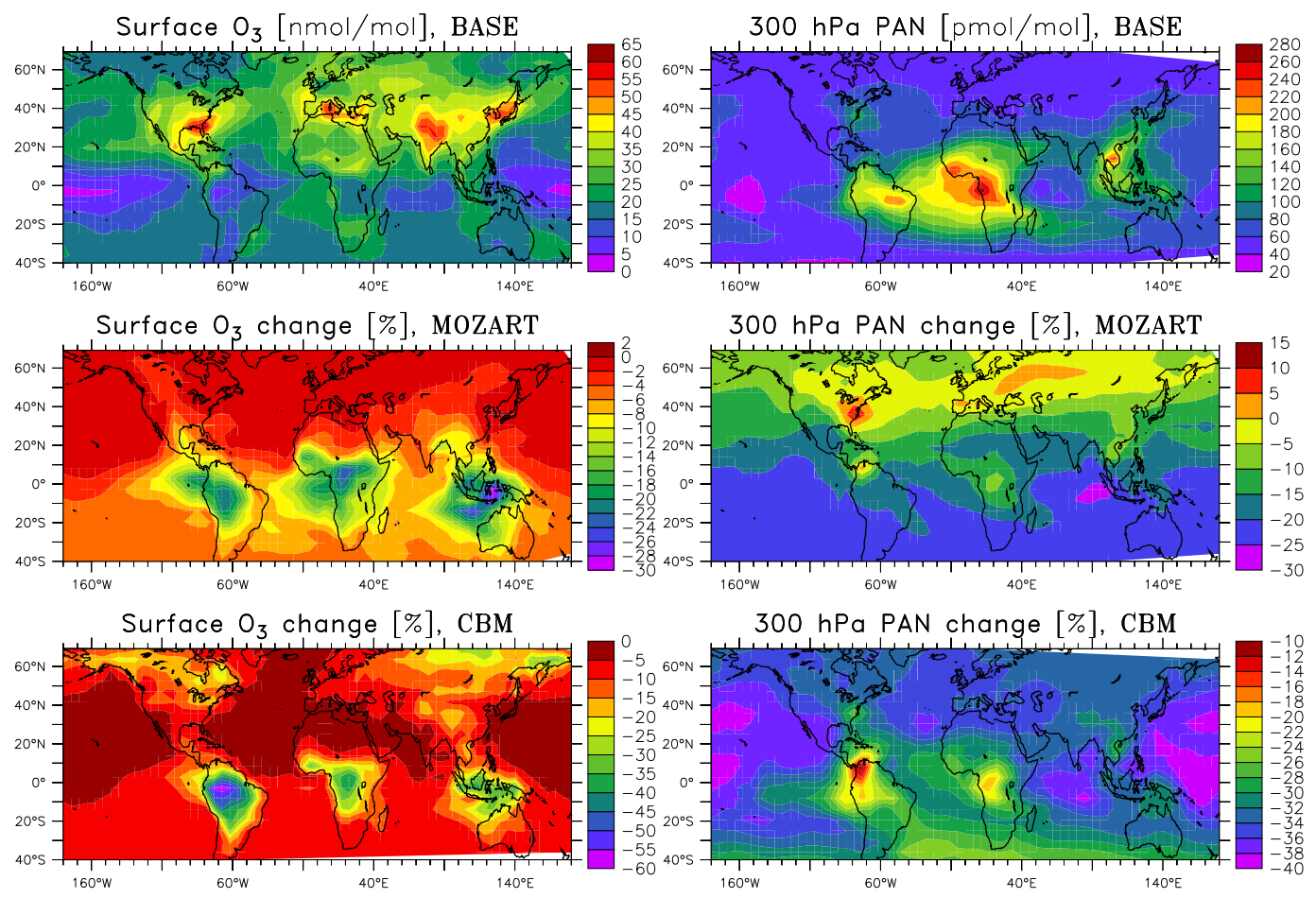

Fig. 2. Distribution of surface ozone and $P A N$ at $300 \mathrm{hPa}$ in the BASE run (upper two panels) and relative difference (in $\%$ ) of the results from the MOZART (middle panels) and CBM (lower panels) from the BASE run (e.g. $\left.\left(\mathrm{X}_{M O Z A R T}-\mathrm{X}_{B A S E}\right) / \mathrm{X}_{B A S E} \cdot 100 \%\right)$.

(ISON, Table 1). Since both groups still include a double bond they can react readily with $\mathrm{OH}$, but the reaction products and their properties are not well known (Atkinson, 1994; Carter and Atkinson, 1996). Chen et al. (1998) argued that permanent removal of $\mathrm{NO}_{\mathrm{x}}$ will generally occur. In the MIM an intermediate product, denoted NACA (for nitrooxyacetaldehyde) is formed which can also deposit. In the sensitivity run NONACA it was assumed that all products of the ISON+OH reaction are lost through deposition (dry or wet). Another assumption (Roelofs and Lelieveld, 2000) is that ISON quickly reacts to form $\mathrm{HNO}_{3}$, which is tested in the INHNO3 run (Table 3). It is noted, however, that experimental support for this assumption is lacking.

\subsection{Deposition of intermediates}

A last group of sensitivity runs is performed to assess the role of deposition processes of soluble intermediates in the oxidation of isoprene. Due to the additional polar hydroxy group in ISOOH and MACROOH and considering the fact that another functional group could be formed through $\mathrm{OH}$ attack at the remaining double bond these hydroxyhydroperoxides are probably very soluble and could therefore be efficiently taken up by cloud droplets and possibly to other surfaces. The special role and properties of these hydroxy-hydroperoxides compared to other peroxyradicals $(\mathrm{ROOH})$ is often neglected (e.g. Berntsen and Isaksen, 1997; Collins et al., 1999; Zaveri and Peters, 1999).
This is imitated in the LOWDEP run, where the solubility of $\mathrm{CH}_{3} \mathrm{OOH}$ is assumed to also be valid for these compounds, with effect of a lower wet and dry deposition efficiency. In the standard simulation the solubility of hydroxymethyl hydroperoxide $\left(\mathrm{HOCH}_{2} \mathrm{OOH}\right)$ has been used for these species (i.e. 1.7.10 $\mathrm{M} / \mathrm{atm}$ at $298 \mathrm{~K}$, O'Sullivan et al., 1996).

An even more extreme case is tested in VLOWDEP, where deposition (dry and wet) of several intermediates (ISOOH, MACROOH, HACET, MPAN, MACR, ISON) in the MIM are neglected completely. On the other extreme, in the "HIGHDEP" simulation a 70\% loss of ISOOH and MACROOH is assumed as in Müller and Brasseur (1995); Brasseur et al. (1998) and Granier et al. (2000).

\section{Sensitivity to the chemical scheme}

The horizontal distribution of ozone and PAN along with the changes resulting from the different isoprene oxidation mechanisms is shown in Fig. 2. A summary of selected budgets and minimal and maximal relative and absolute effects found in all sensitivity runs is given in Tables 4 and 5 to provide more information and will be discussed later.

As expected, the changes are largest over the tropical rainforest regions, where isoprene emissions are highest (Fig. 2). An exception is the large increase in PAN in the northern latitudes for MOZART. This mechanism appears to produce significantly more PAN under medium to high- $\mathrm{NO}_{\mathrm{x}}$ condi- 
Table 4. Selected budgets numbers from the sensitivity simulations for May. Units are $\mathrm{Tg} / \mathrm{yr}$ unless stated differently.

\begin{tabular}{|c|c|c|c|c|c|c|c|c|c|c|c|c|c|}
\hline Test case $^{a}$ & $\mathrm{CH} 4$ & BASE & $\begin{array}{l}\text { MOZ- } \\
\text { ART }\end{array}$ & $\mathrm{CBM}$ & $\begin{array}{l}\text { LOW- } \\
\text { ISOP }\end{array}$ & $\begin{array}{l}\text { LOW- } \\
\text { SOIL }\end{array}$ & $\begin{array}{l}\text { LOW- } \\
\text { LTNG }\end{array}$ & $\begin{array}{l}\text { HIGH- } \\
\text { ISON }\end{array}$ & $\begin{array}{c}\mathrm{IN}- \\
\mathrm{HNO}_{3} \\
\end{array}$ & $\begin{array}{c}\mathrm{NO}- \\
\mathrm{NACA}\end{array}$ & $\begin{array}{l}\text { VLOW- } \\
\text { DEP }\end{array}$ & $\begin{array}{l}\text { LOW- } \\
\text { DEP }\end{array}$ & $\begin{array}{l}\text { HIGH- } \\
\text { DEP }\end{array}$ \\
\hline \multicolumn{14}{|l|}{$\mathrm{O}_{3}$ Troposphere } \\
\hline Burden $[\mathrm{Tg}]$ & 273 & 304 & 290 & 291 & 296 & 304 & 298 & 303 & 297 & 298 & 322 & 308 & 300 \\
\hline Dry deposition & -604 & -724 & -684 & -707 & -713 & -719 & -718 & -705 & -702 & -705 & -765 & -730 & -715 \\
\hline $\mathrm{P}\left(\mathrm{O}_{3}\right)-\mathrm{L}\left(\mathrm{O}_{3}\right)^{b}$ & -80 & 90 & 37 & 54 & 56 & 85 & 86 & 71 & 58 & 63 & 190 & 115 & 66 \\
\hline $\mathrm{P}\left(\mathrm{O}_{3}\right)$ & 3087 & 3956 & 3645 & 3669 & 3758 & 3938 & 3881 & 3908 & 3785 & 3808 & 4345 & 4041 & 3860 \\
\hline$-\mathrm{L}\left(\mathrm{O}_{3}\right)$ & -3167 & -3865 & -3609 & -3615 & -3702 & -3853 & -3795 & -3837 & -3727 & -3745 & -4155 & -3927 & -3793 \\
\hline \multicolumn{14}{|l|}{$\mathrm{O}_{3}$ Continental $\mathrm{PBL}^{c}$} \\
\hline Transport $^{d}$ & 4 & -50 & -6 & 13 & -52 & -45 & -52 & -32 & -29 & -31 & -58 & -41 & -53 \\
\hline $\mathrm{P}\left(\mathrm{O}_{3}\right)-\mathrm{L}\left(\mathrm{O}_{3}\right)$ & 410 & 564 & 487 & 495 & 559 & 554 & 561 & 527 & 525 & 530 & 603 & 559 & 561 \\
\hline \multicolumn{14}{|l|}{ CO Troposphere } \\
\hline Burden [Tg] & 271 & 302 & 298 & 300 & 288 & 302 & 305 & 302 & 304 & 305 & 315 & 313 & 294 \\
\hline Chem. Prod. & 787 & 1081 & 958 & 1023 & 989 & 1078 & 1066 & 1071 & 1037 & 1045 & 1234 & 1138 & 1031 \\
\hline Chem. Loss. & -2068 & -2244 & -2136 & -2159 & -2184 & -2240 & -2223 & -2232 & -2194 & -2201 & -2360 & -2270 & -2212 \\
\hline $\mathrm{CH}_{4}$-Lifetime [yr] & 8.70 & 8.91 & 9.25 & 9.23 & 8.75 & 8.94 & 9.08 & 8.98 & 9.21 & 9.20 & 8.75 & 9.07 & 8.82 \\
\hline $\begin{array}{l}\text { NO }_{y} \\
\text { Troposph. Burden }[\mathrm{Gg}-\mathrm{N}]\end{array}$ & 198 & 314 & 310 & 278 & 273 & 313 & 305 & 317 & 294 & 299 & 419 & 349 & 285 \\
\hline Transp. Continental PBL & -2.86 & -4.42 & -4.13 & -3.98 & -4.04 & -4.36 & -4.39 & -4.42 & -3.85 & -3.97 & -5.93 & -4.64 & -4.26 \\
\hline Transp. UT Tropics ${ }^{e}$ & 0.270 & 0.111 & -0.094 & 0.075 & 0.24 & 0.098 & 0.143 & 0.094 & 0.07 & 0.103 & 0.136 & 0.045 & 0.202 \\
\hline \multicolumn{14}{|l|}{ PAN } \\
\hline Burden $[\mathrm{Gg}-\mathrm{N}]$ & - & 84 & 72 & 57 & 53 & 84 & 81 & 85 & 78 & 82 & 147 & 111 & 60 \\
\hline Transp. Continental PBL & - & -0.766 & -0.832 & -0.595 & -0.639 & -0.756 & -0.754 & -0.705 & -0.701 & -0.72 & -1.174 & -0.887 & -0.689 \\
\hline Transport, UT Tropics & - & -0.227 & -0.173 & -0.14 & -0.08 & -0.23 & -0.206 & -0.243 & -0.218 & -0.227 & -0.386 & -0.298 & -0.135 \\
\hline
\end{tabular}

${ }^{a}$ For a list of acronyms of the runs see Table 3 .

${ }^{b}$ Net photochemical production, based on the extended $\mathrm{O}_{3}$ family. $\mathrm{P}\left(\mathrm{O}_{3}\right)$ is gross chemical production and $\mathrm{L}\left(\mathrm{O}_{3}\right)$ chemical loss of ozone.

${ }^{c}$ Continental boundary layer (below about $800 \mathrm{hPa}, \sigma>0.778, \sigma=p / \mathrm{p}_{\text {surface}}$ ). Continents are defined by the model's land-sea mask.

${ }^{d}$ Sum of advection, convection and vertical diffusion tendencies. Negative numbers indicate net export from the region.

${ }^{e}$ Tropical upper troposphere $\left(20^{\circ} \mathrm{S}-20^{\circ} \mathrm{N}, \sigma<0.34\right)$.

tions as found in this region. The effect in the extra-tropics is not fully developed in early summer. However, in the south-eastern U.S. there is a region where ozone production from industrial $\mathrm{NO}_{\mathrm{x}}$ and isoprene has already increased ozone mixing ratios significantly above the background values. The three mechanisms agree to within a few percent in their calculation of ozone levels in this region, reflecting that they have been originally tuned and tested for these conditions.

In the tropical continental regions, where $\mathrm{NO}_{\mathrm{x}}$ concentration are lower, however, differences of up to $50 \%$ are seen. The MOZART scheme results in about 15-30\% lower ozone concentrations in the source region and the CBM mechanisms yields even lower values, especially in the clean Amazon basin. This is a result of the lower $\mathrm{NO}_{\mathrm{x}}$ mixing ratios calculated by the two mechanisms as a result of stronger alkylnitrate formation (in line with the box model results, Pöschl et al. (2000)).

In case of the CBM scheme, in the Amazon region a decrease in surface mixing ratios (not shown) of $\mathrm{NO}_{\mathrm{x}}(10$ $20 \%)$, PAN (20-50\%) and OH (25-45\%), but an increase in $\mathrm{HO}_{2}$ is found compared to the BASE run. For the MOZART scheme, on the other hand, $\mathrm{NO}_{\mathrm{x}}, \mathrm{HO}_{2}$ and $\mathrm{OH}$ have decreased only slightly ( $\approx 5 \%$, not shown), but PAN is also decreased over the Amazon region by $20-40 \%$. A likely cause for the lower PAN levels are the implicit assumptions of large losses of intermediates in both schemes. In the CBM mechanism this is expressed in the 50\% loss of carbon upon the initial reaction with $\mathrm{OH}$. Strong carbon loss in MOZART occurs through the assumption of a $70 \%$ loss of the hydroxyhydroperoxides.

The global average $\mathrm{CO}$ yield from isoprene in the two schemes can be estimated using information from the methane-only run: Assuming that the CO-yield from methane does not vary significantly when adding isoprene chemistry we calculate the overall CO-yield from isoprene of each scheme on a per carbon basis. Consistent with the consideration above for CBM (0.33) and MOZART (0.25) a lower $\mathrm{CO}$ yield is calculated for May than for the MIM with a CO-yield of 0.37 .

Comparing the calculated average loss fraction of the hydroxy-hydroperoxides in MIM to the assumed fixed $70 \%$ in MOZART can further explain the low yield in the MOZART run. For the BASE run (using the MIM scheme) 
Table 5. Maximal relative and absolute deviations of the test runs from the BASE run. The relative deviations have been restricted to regions where the mixing ratios are more than $5 \%$ of the corresponding lower tropospheric $(<500 \mathrm{hPa})$ average.

\begin{tabular}{|c|c|c|c|c|c|c|c|c|c|c|c|c|}
\hline Test run ${ }^{a}$ & $\mathrm{CH} 4$ & $\begin{array}{c}\text { MOZ- } \\
\text { ART }\end{array}$ & CBM & $\begin{array}{l}\text { LOW- } \\
\text { ISOP }\end{array}$ & $\begin{array}{l}\text { LOW- } \\
\text { SOIL }\end{array}$ & $\begin{array}{l}\text { LOW- } \\
\text { LTNG }\end{array}$ & $\begin{array}{l}\text { HIGH- } \\
\text { ISON }\end{array}$ & $\begin{array}{c}\mathrm{IN}- \\
\mathrm{HNO}_{3} \\
\end{array}$ & $\begin{array}{c}\text { NO- } \\
\text { NACA }\end{array}$ & $\begin{array}{c}\text { VLOW- } \\
\text { DEP }\end{array}$ & $\begin{array}{l}\text { LOW- } \\
\text { DEP }\end{array}$ & $\begin{array}{c}\text { HIGH- } \\
\text { DEP }\end{array}$ \\
\hline \multicolumn{13}{|l|}{$\mathbf{O}_{3}$} \\
\hline max. relative change $[\%]^{b}$ & 4.7 & 0.5 & 0.4 & 15.8 & 0.2 & 0.3 & 3.6 & 0.2 & 0.2 & 41.8 & 16.0 & 2.0 \\
\hline min. relative change $[\%]^{c}$ & -48.2 & -34.5 & -63.4 & -14.6 & -15.7 & -25.1 & -28.4 & -19.1 & -17.1 & -0.5 & -11.6 & -3.8 \\
\hline max. absolute change $[\mathrm{nmol} / \mathrm{mol}]^{d}$ & 11.0 & 6.6 & 4.6 & 4.2 & 0.15 & 4.1 & 0.7 & 1.8 & 1.5 & 8.1 & 2.1 & 1.0 \\
\hline $\min$. absolute change $[\mathrm{nmol} / \mathrm{mol}]$ & -23.9 & -11.2 & -12.5 & -5.7 & -2.5 & -8.6 & -5.1 & -6.5 & -5.8 & -6.2 & -3.2 & -1.1 \\
\hline \multicolumn{13}{|l|}{$\mathrm{CO}$} \\
\hline max. relative change [\%] & 1.4 & 1.4 & 12.8 & 0.1 & 0.6 & 5.2 & 1.1 & 2.0 & 2.3 & 25.0 & 15.7 & 0.0 \\
\hline min. relative change [\%] & -42.9 & -10.2 & -10.3 & -18.9 & -1.4 & -0.5 & -3.6 & -2.0 & -1.4 & 0.0 & 0.0 & -5.1 \\
\hline max. absolute change $[\mathrm{nmol} / \mathrm{mol}]$ & 1.8 & 1.9 & 16.0 & 0.01 & 0.6 & 3.5 & 1.3 & 1.4 & 1.9 & 35.8 & 20.6 & 0 \\
\hline $\min$. absolute change $[\mathrm{nmol} / \mathrm{mol}]$ & -77.9 & -11.7 & -22.4 & -33.7 & -1.6 & -0.6 & -4.0 & -2.3 & -1.7 & -0 & -0 & -5.9 \\
\hline \multicolumn{13}{|l|}{$\mathrm{NO}_{\mathbf{x}}$} \\
\hline max. relative change $[\%]$ & 83.2 & 14.3 & 24.7 & 52.2 & 8.3 & 11.9 & 20.4 & 5.8 & 5.5 & 179.7 & 105.8 & 20.7 \\
\hline min. relative change [\%] & -79.2 & -70.0 & -73.4 & -49.6 & -38.1 & -54.8 & -32.3 & -41.4 & -38.0 & -23.1 & -48.1 & -17.1 \\
\hline max. absolute change $[\mathrm{pmol} / \mathrm{mol}]$ & 2486 & 31.8 & 1537 & 89.6 & 3.5 & 15.6 & 98.7 & 25.4 & 25.5 & 89.5 & 23.9 & 42.2 \\
\hline min. absolute change $[\mathrm{pmol} / \mathrm{mol}]$ & -260 & -127 & -173 & -46.7 & -223 & -79.1 & -74.0 & -64.1 & -57.3 & -267 & -39.1 & -13.6 \\
\hline \multicolumn{13}{|l|}{ PAN } \\
\hline max. relative change [\%] & - & 79.5 & 114.0 & 13.8 & 19.9 & 31.6 & 69.4 & 44.0 & 51.0 & 1924 & 1072 & 0.8 \\
\hline min. relative change [\%] & - & -81.1 & -85.6 & -88.8 & -24.2 & -33.4 & -38.0 & -45.1 & -39.6 & -14.0 & -19.5 & -48.3 \\
\hline max. absolute change $[\mathrm{pmol} / \mathrm{mol}]$ & - & 497 & 37 & 2.2 & 4.0 & 2.1 & 13.5 & 0.6 & 1.2 & 617 & 195 & 1.0 \\
\hline $\min$. absolute change $[\mathrm{pmol} / \mathrm{mol}]$ & - & -118 & -189 & -352 & -29.0 & -54.8 & -80.1 & -64.9 & -52.6 & -1.2 & -1.6 & -78.4 \\
\hline \multicolumn{13}{|l|}{ OH } \\
\hline max. relative change [\%] & 6854 & 11.6 & 51.0 & 229 & 1.2 & 7.2 & 3.4 & 3.2 & 1.7 & 35.5 & 11.9 & 25.8 \\
\hline min. relative change $[\%]$ & -49.8 & -59.8 & -67.9 & -14.7 & -25.4 & -59.1 & -45.7 & -27.4 & -26.0 & -60.3 & -60.4 & -7.2 \\
\hline \multicolumn{13}{|l|}{$\mathrm{HO}_{2}$} \\
\hline min. relative change [\%] & -93.7 & -20.1 & -39.2 & -39.7 & -8.1 & -13.4 & -12.5 & -12.6 & -10.9 & -12.3 & -19.1 & -14.2 \\
\hline
\end{tabular}

${ }^{a}$ For a list of acronyms of the runs see Table 3.

${ }^{b}$ Percentage by which the mixing ratio in the test run is maximally higher than the BASE run.

${ }^{c}$ Percentage by which the mixing ratio in the test run is maximally lower than the BASE run.

${ }^{d}$ Like relative changes, but for maximum difference in mixing ratios.

a global loss fraction of $35 \%$ of the hydroxy-hydroperoxides is calculated. Over the Amazon rain forest during May this loss fraction is $68 \%$ in the BASE run which is in qualitative agreement with the 1D model study of Jacob and Wofsy (1990) upon which Brasseur et al. (1998) based their general loss rate of $70 \%$. However, the fraction is found to depend strongly on the $\mathrm{OH}$ concentrations since they limit the chemical lifetimes of these compounds. Consequently, in the free troposphere (above $800 \mathrm{hPa}$ ) the fraction of hydroxyhydroperoxides lost via deposition is calculated to be much smaller (about 10\%), because the photochemical loss via reaction with $\mathrm{OH}$ and photolysis is faster (the $24 \mathrm{~h}$-average lifetime is about $12 \mathrm{~h}$ for those conditions). This also means that the loss of carbon via this pathway will actually depend on the assumed emission strength of isoprene, because this largely controls the abundance of $\mathrm{OH}$ in the boundary layer where most of the loss occurs. The reactivity of the group of intermediates will also be important, adding to the overall uncertainty. Although large uncertainties exist these consid- erations argue against the use of fixed loss fractions and for an explicit treatment of these soluble intermediates and their spatially and temporally varying deposition rates.

The deviations in the PAN concentration at $300 \mathrm{hPa}$ in the UT are also plotted in Fig. 2. The upper tropospheric values are plotted here because they determine the large scale transport of $\mathrm{NO}_{\mathrm{x}}$ and give a better indication of the impact of the chemical scheme on the background level of this compound. Interestingly, for MOZART higher PAN concentrations are calculated near the surface in the northern hemispheric extra-tropics $(+40-60 \%)$, but the difference in the upper troposphere is much smaller $( \pm 5 \%)$. In these regions the treatment of the hydroxy-hydroperoxides is probably not important due to higher $\mathrm{NO}_{\mathrm{x}}$ and $\mathrm{OH}$ concentrations.

In CBM the calculated concentration of upper tropospheric PAN is lower by about $20-40 \%$ compared to the MIM-chemistry (BASE run) over large regions including the $\mathrm{NH}$-extra-tropics. Near the surface the CBM scheme tends to calculate lower mixing ratios over the continents and most 



Surface $\mathrm{O}_{3}$ change [\%], LOWLTNG

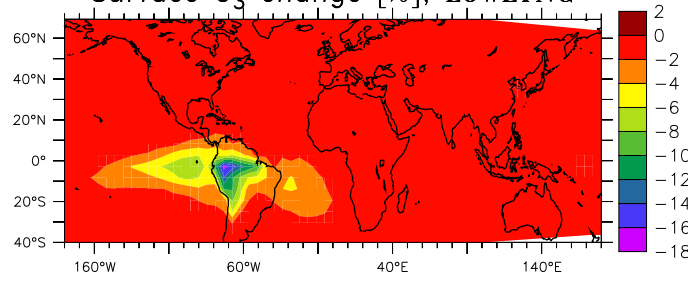

$300 \mathrm{hPa}$ PAN change [\%], LOWLTNG

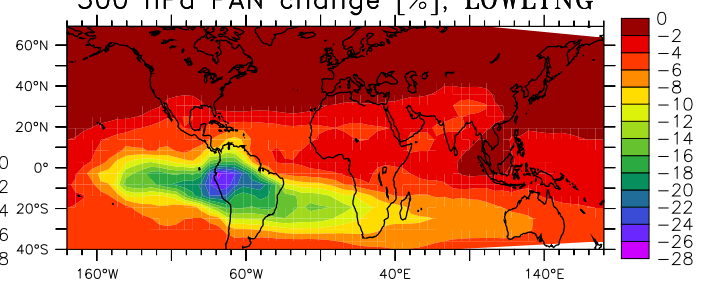

Surface $\mathrm{O}_{3}$ change [\%], LOWSOIL

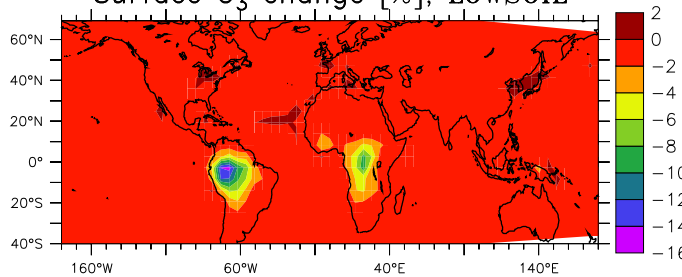

Surface $\mathrm{NO}_{x}$ change [\%], LOWSOIL

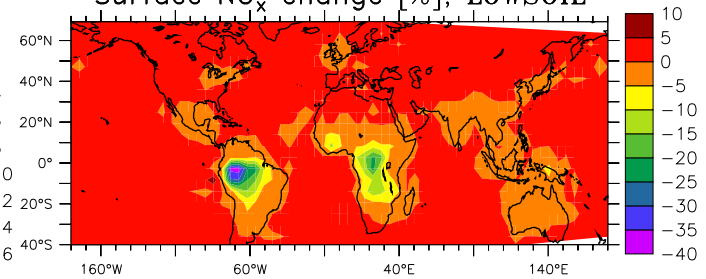

Fig. 3. Relative change (in \%) in surface ozone and PAN at $300 \mathrm{hPa}$ in the sensitivity runs with changed emissions. For the LOWSOIL simulation the change in surface $\mathrm{NO}_{\mathrm{x}}$ is plotted.

parts of the ocean (not shown). Taking into account that PAN in the CBM scheme actually encompasses all PAN-type species would increase the difference between the BASE and the CBM run.

These results are consistent with the findings from the box model simulations of Pöschl et al. (2000) for high and low $\mathrm{NO}_{\mathrm{x}}$ scenarios. For high $\mathrm{NO}_{\mathrm{x}}$ the MIM was found to be was bracketed by the two schemes in the, with MOZART being higher and CBM being lower. Under low $\mathrm{NO}_{\mathrm{x}}$ was found to yield more PAN than the two other schemes.

The tropospheric burden of PAN (Table 4) is lower in MOZART $(-14 \%)$ and in the CBM run $(-32 \%)$ compared the BASE run. However, the export from the continental troposphere is largest in MOZART and significantly smaller in CBM. This means that higher efficiency of the MIM at medium to low $\mathrm{NO}_{\mathrm{x}}$ levels outweighed its lower efficiency compared to the MOZART scheme on the global average. The net export of PAN from the tropical upper troposphere shows that in this region chemistry is a source of PAN underlining its important role in the long-range transport of $\mathrm{NO}_{\mathrm{x}}$. Significant deviations are also found for total reactive nitrogen $\left(\mathrm{NO}_{\mathrm{y}}\right)$, with the lowest values generally found for the CBM simulation (Table 4).

The global tropospheric burden of ozone is lower by about $5 \%$ in the two other chemistry schemes. The results from a "methane-only" $\left(\mathrm{CH}_{4}-\mathrm{CO}-\mathrm{NO}_{\mathrm{x}}-\mathrm{HO}_{\mathrm{x}}\right)$ simulation are also listed in order to assess the error in the overall effect of iso- prene. While in the BASE run an increase of $31 \mathrm{Tg}\left(\mathrm{O}_{3}\right)$ compared to the $\mathrm{CH} 4$ run is calculated, it is only 17 or $18 \mathrm{Tg}$ in the other two runs. The gross production of ozone $\left(\mathrm{P}\left(\mathrm{O}_{3}\right)\right)$ varies by as much as $300 \mathrm{Tg}\left(\mathrm{O}_{3}\right) / \mathrm{yr}$ in the different isoprene runs, with an average increase compared to the $\mathrm{CH} 4$ simulation of about 700-800 Tg/yr. However, the change (decrease or increase) in the loss rate is always in line with the production change, so that the change in net production is not as large.

For the globally averaged export (or import) of ozone from the continental boundary layer even different signs are predicted. The BASE run has the highest photochemical production of ozone and despite a compensating higher dry deposition rate it results in the largest export of ozone from this region.

The CO burden is only marginally different in the runs, but it could be that the spin-up time of 2 months is not sufficient to fully develop the effect for this longer lived species. The production rate is significantly lower in MOZART ($123 \mathrm{Tg}(\mathrm{CO}) / \mathrm{yr}$ or $11 \%)$ and CBM $(-58 \mathrm{Tg} / \mathrm{yr}, 5 \%)$ due to the implicit loss assumptions in the two schemes. Despite the lower production rates and burdens of $\mathrm{CO}$ in these two runs, the oxidation efficiency of the atmosphere with respect to methane is somewhat lower (corresponding to a 0.3 years longer methane lifetime). Thus, for CO probably two effects are competing: reduced production in the MOZART and CBM simulation due to higher losses of intermediates act 


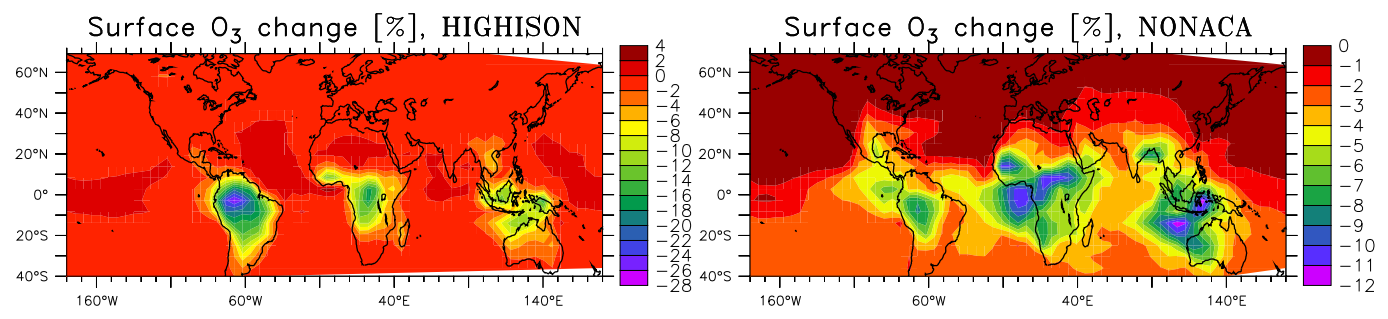

Fig. 4. Relative change (in \%) in surface ozone in the HIGHISON and NONACA sensitivity runs compared to the BASE run.

against lower loss of $\mathrm{CO}$ due to lower $\mathrm{OH}$ levels in these runs. The latter is probably caused by the lower PAN amounts and thus less long-range transport of $\mathrm{NO}_{\mathrm{x}}$.

Locally, the effects on $\mathrm{CO}$ mixing ratios can also be significant (Table 5). It can be seen that the MOZART and CBM simulation can be as much as 11 and $22 \mathrm{nmol} / \mathrm{mol}$ lower in $\mathrm{CO}$. For the CBM scheme regions with higher $\mathrm{CO}$ mixing ratios (up to $12 \mathrm{nmol} / \mathrm{mol}$ ) are also found, which is probably due the faster oxidation of isoprene to $\mathrm{CO}$ resulting from the omission of several intermediate stages in the mechanism. The maximum perturbation in $\mathrm{O}_{3}$ is as large as about 10 $\mathrm{nmol} / \mathrm{mol}$ for two chemistry schemes. Local deviations are also found for the two $\mathrm{HO}_{\mathrm{x}}$ species $\left(\mathrm{OH}\right.$ and $\left.\mathrm{HO}_{2}\right)$, especially for the CBM simulation.

\section{Sensitivity to the emissions strengths}

The effects on surface ozone and PAN at $300 \mathrm{hPa}$ due to perturbations of the emission strengths are shown in Fig. 3. The perturbation of upper tropospheric PAN in the LOWSOIL simulation was small $( \pm 2 \%)$ so that the change in surface $\mathrm{NO}_{\mathrm{x}}$ concentrations is shown instead.

The reduction of the isoprene emissions in the tropics (LOWISOP) results in an increase of $\mathrm{O}_{3}$ in the source regions, which is due to the reduced ozonolysis of isoprene. On the other hand, a decrease in remote regions and also in the free troposphere above the source regions is calculated (not shown), which is likely connected to less PAN formation and thus less $\mathrm{NO}_{\mathrm{x}}$ in remote regions. The absolute difference (Table 5) in $\mathrm{O}_{3}$ of about $\pm 5 \mathrm{nmol} / \mathrm{mol}$ is not as large as those found using different chemical schemes.

The predicted increase in the total ozone column in the BASE run compared to a "methane-only" simulation (CH4) of $31 \mathrm{Tg}\left(\mathrm{O}_{3}\right)$ is reduced by $8 \mathrm{Tg}$ (i.e. $26 \%$ of the effect). Interestingly, the tropospheric burden and the net production term of $\mathrm{O}_{3}$ in the LOWISOP simulation are still higher than for the MOZART and the CBM runs, whereas other budget numbers like the global $\mathrm{CO}$ burden and chemical production and the global PAN burden are significantly lower in the LOWISOP run. This shows that the impact of the isoprene oxidation scheme on $\mathrm{O}_{3}$ is roughly comparable to the $50 \%$ reduction in isoprene source strength, whereas most other species show smaller deviations in the LOWISOP compared to using different chemical schemes.

A larger impact is predicted for PAN, which is reduced by about $40-60 \%$ at $300 \mathrm{hPa}$ in the LOWISOP run, suggesting an approximately linear response to the $50 \%$ reduction in isoprene emissions. If the overestimate of isoprene concentrations is due to overestimated isoprene emissions or a missing non-chemical sink this could together with the fact that a large $(>50 \%)$ fraction of PAN in the tropics is from isoprene (von Kuhlmann, 2001) explain a large part of the overestimate in PAN found by von Kuhlmann et al. (2003b).

The reduction of the soil emissions (or the canopy reduction factor) results in a maximum reduction of $\mathrm{NO}_{\mathrm{x}}$ of $38 \%$ (Table 5 and Fig. 3) over the central Amazon and a reduction in $\mathrm{O}_{3}$ of about $15 \%$, only $2.5 \mathrm{nmol} / \mathrm{mol}$. In the free troposphere the effect on ozone and as mentioned above also on PAN is negligible $\left(\mathrm{O}_{3}:< \pm 1 \%\right)$. Recall, however, that the absolute change in the emission strength was only small in this test run.

A much larger effect is found when reducing lightning $\mathrm{NO}_{\mathrm{x}}$ emissions over the Amazon region (LOWLTNG run). The $60 \%$ reduction in the lightning NO source reduces PAN concentrations by up to $30 \%$ in that region in the LOWLTNG run. If we could assume a linear response from this, we could estimate that about half of the PAN formed from isoprene in that region is from the interaction of isoprene oxidation products and lightning $\mathrm{NO}_{\mathrm{x}}$. However, linearity is probably not fulfilled so that this estimate will give only an indication of the magnitudes. The remaining PAN is formed from $\mathrm{NO}_{\mathrm{x}}$ from biomass burning (in Venezuela), some surrounding industrial emissions (e.g. from cities at the west coast of South America) and from $\mathrm{NO}_{\mathrm{x}}$ emissions from soils. The overestimate of the simulated $\mathrm{NO}_{2}$-column over the central Amazon in May compared to GOME retrievals found in von Kuhlmann (2001) was as large as a factor of 10. Thus, even when considering the uncertainties in that comparison, it is possible that the $60 \%$ reduction was too mild. Besides a still overestimated lightning- $\mathrm{NO}_{\mathrm{x}}$ source also an overestimated $\mathrm{NO}_{\mathrm{x}}$ lifetime and other $\mathrm{NO}_{\mathrm{x}}$ sources could play a role.

However, a better quantification of the source strength of lightning in this region, especially in the wet season, when other $\mathrm{NO}_{\mathrm{x}}$ sources are weak (and deposition loss is strongest), in connection with a realistic representation of 
Table 6. Tropospheric budgets of $\mathrm{C}_{5}$-isoprene nitrates in the BASE simulation (MIM chemistry) in May. Numbers are in $\mathrm{Tg}(\mathrm{N}) / \mathrm{yr}$.

\begin{tabular}{lll}
\hline Sources & $\mathrm{C}_{5} \mathrm{H}_{8}+\mathrm{NO}_{3}$ & +2.9 \\
& $\mathrm{ISO}_{2}+\mathrm{NO}$ & +1.8 \\
\hline \multirow{2}{*}{ Sinks } & $\mathrm{ISON}+\mathrm{OH}$ & -2.2 \\
& $\mathrm{ISON}+\mathrm{h} v$ & -0.1 \\
& dry deposition & -1.0 \\
& wet deposition & -1.5 \\
\hline
\end{tabular}

vertical transport (PBL turbulence, convection) appears to be a key to a better simulation of the chemistry over the Amazon, and significantly influences the export of PAN from that region.

\section{Sensitivity to the fate of isoprene-nitrates}

The nitrates formed in the oxidation of isoprene are usually represented by only a few surrogate species in the condensed mechanisms, due to a lack of more detailed knowledge of their individual chemistry and computational restrictions. Apart from the uncertainty in their formation rate, it is also largely unknown what products are formed upon their reaction with $\mathrm{OH}$ or photolysis.

The changes of surface ozone in the HIGHISON and NONACA simulations are shown in Fig. 4 and further results are listed in Tables 4 and 5. Ozone concentrations decrease by about $10-20 \%$ in the central Amazon region in these two runs. The peak effect of an increased nitrate formation rate $\left(8.8 \%\right.$ of the $\mathrm{ISO}_{2}+\mathrm{NO}$ reaction) is higher, whereas the changes in the simulation in which all products of the reaction of isoprene nitrates with $\mathrm{OH}$ (ISON+OH) are assumed to deposit (NONACA) are more widespread. As mentioned before a higher yield of isoprene nitrates is actually supported by a recent laboratory study (Sprengnether et al., 2002).

The results from the third run in which all ISON is quickly converted to $\mathrm{HNO}_{3}$ (INHNO3) is not shown, since it yielded very similar results than the NONACA simulation. This is understandable, because forming $\mathrm{HNO}_{3}$ from ISON will also result in a high likelihood of permanent nitrogen removal from the atmosphere, but in this case via deposition of nitric acid instead of an explicit assumption in the scheme.

The global average sources and sinks of the surrogate species ISON in the MIM are listed in Table 6. It is calculated that more than $60 \%$ of the ISON surrogate in MIM is formed from the nighttime reaction of isoprene with $\mathrm{NO}_{3}$. The isoprene- $\mathrm{NO}_{3}$-adduct could in principle react with $\mathrm{NO}$, $\mathrm{NO}_{3}, \mathrm{HO}_{2}, \mathrm{OH}$ or decompose (Jenkin et al., 1997), but no mechanistic information is available at present and as mentioned before the SAR estimation method for nitrates is not very reliable. Studies investigating this product group should mainly focus on the question of how much of the nitrates are eventually lost from the atmosphere without releasing $\mathrm{NO}_{2}$. In the BASE case (MIM) about 53\% is lost via dry and wet deposition in May on the global average. This is only slightly higher that the annual average of $48 \%$ calculated in von Kuhlmann (2001). This high fraction is the result of a large Henry's Law constant of $1.7 \cdot 10^{4} \mathrm{M} / \mathrm{atm}$ at $298 \mathrm{~K}$ used for this species. The value obtained by Treves et al. (2000) for 5-nitroxy-2-butanol has been assumed for ISON.

More extreme assumption have been made by Müller and Brasseur (1995), who assume 100\% loss of isoprene nitrates, and by Houweling et al. (1998), who apply deposition properties of PAN also to the nitrates, thus neglecting wet deposition and yielding slower dry deposition than in the other test cases. The first assumption should be similar to the NONACA case tested here, since only a small fraction of ISON photolyzes to give back $\mathrm{NO}_{2}$ (Table 6). The latter assumption is unrealistic and probably a compromise needed because the nitrates from isoprene are not differentiated from the alkyl nitrate pool in their scheme. The tests performed here should thus give a good indication of the actual range of uncertainty from the treatment of isoprene nitrates.

Although the global effects on ozone and PAN are smaller than seen in the test with different chemistry schemes, the local differences in $\mathrm{O}_{3}$ are not negligible (up to $5 \mathrm{nmol} / \mathrm{mol}$ ). The net production in the INHNO3 simulation $(58 \mathrm{Tg} / \mathrm{yr}$ compared to 90 in the BASE run) is almost as low as in the CBM simulation (54 Tg/yr).

\section{Sensitivity to deposition of intermediates}

Two assumptions about deposition properties of soluble intermediate species are tested here (LOWDEP and HIGHDEP, see Table 3). Additionally, for comparison the extreme assumption of a total neglect of deposition of intermediate species is tested in the VLOWDEP scenario. In the BASE case where the hydroxyhydroperoxides (ISOOH and $\mathrm{MACROOH}$ ) are assumed to be relatively soluble a loss fraction of $33 \%$ of these species is calculated on the annual mean. The remaining two thirds photolyse or react with $\mathrm{OH}$. Thus, a loss of 70\% (as HIGHDEP) appears to be only possible when heterogeneous loss on aerosols occurs which is speculative at present.

The effect of these assumptions on ozone is quite small $(<3 \mathrm{nmol} / \mathrm{mol}$ ) for the two more realistic cases (LOWDEP and HIGHDEP), but are predicted to be in the range $\pm 6-8$ $\mathrm{nmol} / \mathrm{mol}$ for the VLOWDEP case (Table 4). For that case also the highest tropospheric burden of $\mathrm{O}_{3}$ of all test simulations is calculated, which corresponds to an increase of 49 $\mathrm{Tg}\left(\mathrm{O}_{3}\right)$ compared to the $\mathrm{CH} 4$ run. This is an over 50\% larger effect than in the BASE case $\left(+31 \mathrm{Tg}\left(\mathrm{O}_{3}\right)\right.$.

The global $\mathrm{CO}$ burdens have changed only slightly as in all the other test runs: $-4 \%$ in LOWDEP and $+2 \%$ in HIGHDEP. But local differences can be especially large in the LOWDEP 

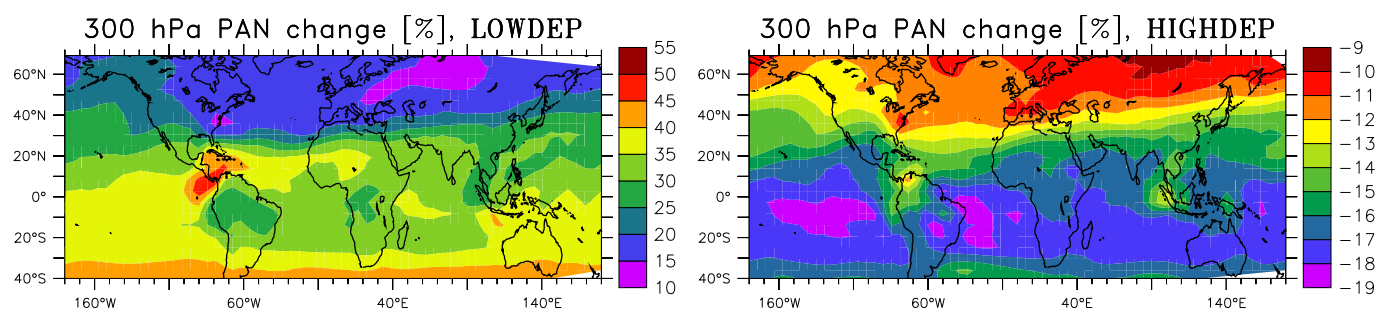

Fig. 5. Change in the PAN mixing ratios (in \%) at $300 \mathrm{hPa}$ for the LOWDEP and HIGHDEP simulations.

run $(+15 \%$ or $20 \mathrm{nmol} / \mathrm{mol})$, though the resulting decrease in $\mathrm{CO}$ in the remote $\mathrm{SH}$ at the surface is also small $(\approx 5 \%$, not shown). This is comparable in magnitude to the effect found by reducing the source strength of isoprene. The photochemical source of $\mathrm{CO}$ is changed by $\pm 50 \mathrm{Tg}(\mathrm{CO}) / \mathrm{yr}(<$ $5 \%$ ) in the two more realistic scenarios and $+150 \mathrm{Tg} / \mathrm{yr}$ in the VLOWDEP case. Note that the magnitude of these effects are also coupled to the total source strength which was reduced by $30 \%$ for all simulations compared to the estimate of Guenther et al. (1995) of $500 \mathrm{Tg}(\mathrm{C}) / \mathrm{yr}$.

An interesting point can be seen in the change in the methane lifetime. While in the two more realistic simulations the methane lifetime changes consistently with the increase or decrease of CO production, in the VLOWDEP the methane lifetime is shorter than in the BASE simulation despite the higher production of $\mathrm{CO}$. This behavior is probably the result of also neglecting the deposition of two nitrates from isoprene oxidation (ISON and MPAN) and the strongly increased PAN abundance (Tables 4 and 5), which lead to enhancement of global $\mathrm{OH}$ via more transport of $\mathrm{NO}_{\mathrm{x}}$ into remote regions.

Since the assumptions in the HIGHDEP simulation are very similar to those implicit in the MOZART mechanism, one can examine the impact of these assumptions on the total difference between MOZART and the BASE run. The difference between the MOZART and HIGHDEP runs are much smaller than those between MOZART and our BASE case. This means that the assumption of $70 \%$ loss of hydroxyhydroperoxides from isoprene in MOZART probably causes a large part of the difference to the MIM scheme used in MATCH-MPIC. Some differences, however, must have other reasons. For instance, the global PAN and $\mathrm{NO}_{\mathrm{y}}$ burdens are even smaller in the HIGHDEP than in the MOZART run which confirms the tendency of the MOZART scheme to predict high PAN levels. Note that PAN-related rate parameters have been harmonized for this study. Thus, other mechanistic assumptions or rate parameters of precursors of the peroxyacetyl radical are responsible for the higher PAN yield in the MOZART mechanism which was also found in the box model study of Pöschl et al. (2000).

The largest effects in this group of test cases is in fact found for PAN, which is depicted in Fig. 5. Especially in the LOWDEP case the deviations are large: A 30-45\% increase in PAN levels can be seen in the upper troposphere
Table 7. Turnover of primary $\mathrm{HO}_{\mathrm{x}}$ source reactions related to isoprene chemistry in $10^{26} \mathrm{molec} / \mathrm{cm}^{3} / \mathrm{s}$ in the tropical upper troposphere $\left(20^{\circ} \mathrm{S}-20^{\circ} \mathrm{N}, \sigma<0.34\right)$ in May.

\begin{tabular}{lllll}
\hline Reaction $\backslash$ Case & $\mathrm{CH}_{4}$ & BASE & LOWDEP & HIGHDEP \\
\hline $\mathrm{HCHO}+\mathrm{h} v^{a}$ & 167.7 & 233.3 & 251.2 & 215.6 \\
$\mathrm{CH}{ }_{3} \mathrm{OOH}+\mathrm{h} v$ & 30.3 & 34.0 & 36.4 & 32.2 \\
$\mathrm{MGLO}+\mathrm{h} v$ & - & 23.7 & 32.0 & 14.9 \\
$\mathrm{HACET}+\mathrm{h} v$ & - & 7.2 & 10.6 & 4.6 \\
$\mathrm{MACROOH}+\mathrm{h} v$ & - & 3.7 & 7.4 & - \\
$\mathrm{MACR}+\mathrm{h} v$ & - & 3.7 & 4.9 & 2.5 \\
$\mathrm{CH}_{3} \mathrm{CO}_{3} \mathrm{H}+\mathrm{h} v$ & - & 0.7 & 1.2 & 0.3 \\
$\mathrm{ISOOH}+\mathrm{h} v$ & - & 0.6 & 0.9 & - \\
\hline Sum & 198.0 & 306.9 & 344.6 & 270.1 \\
Change & $-35 \%$ & - & $+12.3 \%$ & $-12.0 \%$ \\
\hline
\end{tabular}

${ }^{a}$ Turnover of $\mathrm{HCHO}+\mathrm{h} v \rightarrow \mathrm{HCO}+\mathrm{H}$ channel times two.

of the Southern Hemisphere (SH) and the northern tropics when the deposition properties of $\mathrm{CH}_{3} \mathrm{OOH}$ are used for all peroxides (as in the LOWDEP run). The decrease in PAN due to even higher deposition rate is not as large: about 15$20 \%$ over large parts of the $\mathrm{SH}$. The changes in the lower atmosphere are even higher with peak changes of a factor of 10 (see Table 5), but these occur in regions with PAN mixing ratios of only a few $\mathrm{pmol} / \mathrm{mol}$ (e.g. in the south east Pacific).

Since photolysis of peroxides is believed to contribute to upper tropospheric $\mathrm{HO}_{\mathrm{x}}\left(=\mathrm{OH}+\mathrm{HO}_{2}\right)$ production (e.g. Chatfield and Crutzen, 1990; Prather and Jacob, 1997; Jaeglé et al., 1997) it is instructive to see the effect of the different treatment of hydroxy-hydroperoxides on the $\mathrm{HO}_{\mathrm{x}}$ mixing ratios in the this region. In the LOWDEP simulation a $10 \%$ higher zonal mean $\mathrm{HO}_{\mathrm{x}}$ abundance in the uppermost tropical troposphere (100-200 hPa) is found (not shown). The effect on $\mathrm{OH}$ is only slightly smaller (+7\%), although locally the increase is as large as $35 \%$. The HIGHDEP runs results in about $5 \%$ lower zonal mean $\mathrm{HO}_{\mathrm{x}}$ values than in the BASE case. A list of some key reactions contributing to tropical $\mathrm{UT} \mathrm{HO}_{\mathrm{x}}$ is listed in Table 7 . We find that the photolysis of some isoprene oxidation products is at least as important as the photolysis of methyl-hydroperoxide $\left(\mathrm{CH}_{3} \mathrm{OOH}\right)$ identified by Prather and Jacob (1997) as a major contributor. These results qualitatively confirm the findings of Collins 
et al. (1999) that isoprene products can significantly influence $\mathrm{UT} \mathrm{HO}_{\mathrm{x}}$. Note that acetone chemistry is not taken into account here which would constitute additional sources of $\mathrm{HO}_{\mathrm{x}}$ in the upper troposphere (e.g. McKeen et al., 1997). The role of the photolysis of isoprene intermediates in the UT also shows that chemical mechanism reductions which are exclusively based on box-model calculations for the lower troposphere (e.g. Geiger et al., 2003) can lead to errors in large scale 3D models. We find a significant influenced of the assumption about the deposition of intermediates on these result (Table 7) underlining that more accurate knowledge on these properties are needed. Note that the assumption made in Collins et al. (1999) are tested in our case LOWDEP. Furthermore, we find that a large fraction of the additional $\mathrm{HO}_{\mathrm{x}}$ source is through photolysis of formaldehyde formed in the oxidation of isoprene $\left(+65.6 \cdot 10^{26} \mathrm{molec} / \mathrm{cm}^{3} / \mathrm{s}\right.$ in the BASE run compared to the $\mathrm{CH} 4$ simulation, Table 7 ).

\section{Conclusions}

A number of different sensitivities in the treatment of isoprene in a global model have been examined. Different chemical schemes, changed emission rates, and different assumptions about the fate of isoprene nitrates and about the deposition efficiency of certain intermediates have been tested and analyzed for one month of the year (May).

The overall picture obtained in these tests is that global average budget numbers of $\mathrm{O}_{3}$ and $\mathrm{CO}$ vary in the different sensitivity runs by about $5 \%$ or less, whereas the changes in total $\mathrm{NO}_{\mathrm{y}}$ burden and PAN burden are larger $(10 \%$ and $30-40 \%$, respectively). Local deviations of the key species, however, can be substantial.

The 3D model studies reported in this paper confirm the relevance and significance of the differences between the chemical mechanisms investigated in the box model study of Pöschl et al. (2000). On the other hand the results show that transport processes play an important role and that the overall effects of isoprene on global atmospheric chemistry can hardly be quantified by extrapolation of simple box model calculations.

The deviations in the ozone mixing ratios induced when exchanging the chemical scheme were found to be largest among all test simulations. The simulation with the highly condensed CBM-scheme of Houweling et al. (1998) produces the largest local deviations in $\mathrm{O}_{3}$ from the base simulation (up to $60 \%$ or $12 \mathrm{nmol} / \mathrm{mol}$ ). The total tropospheric burden of $\mathrm{O}_{3}$ calculated for the three runs with different chemistry is increased compared to the background methane chemistry by $24 \pm 7 \mathrm{Tg}\left(\mathrm{O}_{3}\right)$ (thus with a range of $\pm 30 \%$ ). The range of effects among all test runs (without the VLOWDEP run, which was intended as an idealized but unrealistic test case) can be expressed as an increase in tropospheric ozone by $26 \pm 9$ (or $\pm 35 \%$ ). This range of uncertainty and the much larger local deviations found in the test runs show that the treatment of isoprene chemistry in global models can only be seen as a first order estimate at present.

The reason for the deviations of the results obtained with different isoprene oxidation mechanisms cannot be easily be explained. However, a comparison to a run in which a major assumption of the MOZART scheme - the constant loss fraction of intermediates - was adopted (HIGHDEP case) suggests that this is a major reason for the differences.

In the case of the CBM scheme (Houweling et al., 1998) it is suspected that in addition to the large loss of carbon and thus also of some functional groups, the direct channeling into smaller products produces the different behavior in that scheme. For this scheme even a different sign for the net transport of ozone out of the global continental boundary layer (thus net import) was calculated in our test set-up.

The MOZART mechanism tends to produce more PAN than the MIM-scheme used in the reference run, but this is in part prevented by the implicit assumption of a high (and constant) loss rate of soluble intermediate species (the hydroxy-hydroperoxides from isoprene). It is argued that the actual loss fraction of these compounds in a certain environment will also depend on the abundance of $\mathrm{OH}$. Although no mechanism can be judged superior over the other schemes, it appears advantageous that these compounds are explicitly included in the MIM. As new data on their reactivities and deposition properties become available, they can be readily implemented in the scheme or the surrounding model.

While deposition of soluble intermediates appeared to have a relatively small impact on ozone, it was found to be much more important for the formation of PAN and thus the resulting total burden of $\mathrm{NO}_{\mathrm{y}}$. The effect of an increased deposition rate resulted in a reduction in the tropospheric PAN burden $(-24 \mathrm{Gg}-\mathrm{N}$, or $-29 \%)$ which was comparable to the effect to a $50 \%$ reduction in the isoprene source strength $(-31$ $\mathrm{Gg}-\mathrm{N},-37 \%$ ). Overall, it appears that the overestimation of modeled PAN compared to observations in the tropics found in another study with MATCH-MPIC (von Kuhlmann et al., 2003 b) could be largely explained by a combination of the three factors found in this study to have the largest impact on PAN: total source strength of isoprene, source strength of lightning $\mathrm{NO}_{\mathrm{x}}$ over regions with large isoprene emissions and loss of intermediates through deposition or possibly heterogeneous processes. All of these parameters need to be quantified better in order to improve the simulation of the long-range transport of $\mathrm{NO}_{\mathrm{x}}$ in the tropics.

A strong impact of isoprene reaction products lifted into the upper troposphere was found, with an uncertainty of about $10 \%$ solely due to the deposition assumptions of the soluble intermediates. A large part of the additional $\mathrm{HO}_{\mathrm{x}}$ is from the photolysis of formaldehyde produced from isoprene.

For some species (e.g. CO, PAN) the effects of a $50 \%$ reduction in tropical isoprene emissions are of the same magnitude as those from exchanging the chemical scheme. While the variation of the release of $\mathrm{NO}$ out of the forest canopy 
had only small effects, reducing the source strength of lightning over the Amazon region by $60 \%$ resulted in larger deviations (up to $20 \%$ in $\mathrm{O}_{3}$ ). The interaction of lightning $\mathrm{NO}_{\mathrm{x}}$ and biogenic hydrocarbons, also other than isoprene, should therefore be further studied.

The effect of the fate of nitrates from the oxidation of isoprene was rather small, but this could be in part due to the chosen season in this study. Larger effects would be for instance expected during the biomass burning season in the southern tropics and sub-tropics.

Overall it can be said that isoprene chemistry is still a relatively uncertain point in current tropospheric chemistry models. In addition to the uncertainties in the the gas-phase mechanisms, deposition and potential heterogeneous processes on aerosols are also issues which require further research.

Acknowledgements. The authors would like to thank P. J. Rasch for continuing MATCH support. We gratefully acknowledge funding from the German Ministry of Education and Research (BMBF), projects $07-\mathrm{ATC}-02$ and $07-\mathrm{ATF}-13$.

\section{References}

Atkinson, R.: Gas-phase tropospheric chemistry of organic compounds, J. Phys. Chem. Ref. Data, Monograph No. 2, 1994.

Bakwin, P. S., Wofsy, S. C., and Fan, S.-M.: Measurements of reactive nitrogen oxides $\left(\mathrm{NO}_{y}\right)$ within and above a topical forest canopy in the wet season, J. Geophys. Res., 95, 16765-16772, 1990.

Berntsen, T. K. and Isaksen, I. S. A.: A global three-dimensional chemical transport model for the troposphere, 1. Model description and CO and ozone results, J. Geophys. Res., 102, 21239 $21280,1997$.

Bottenheim, J. W. and Shepherd, B. F.: $\mathrm{C}_{2}-\mathrm{C}_{6}$ hydrocarbon measurements at four rural locations across Canada, J. Geophys. Res., 29, 647-664, 1995.

Brasseur, G. P., Hauglustaine, D. A., and Walters, S.: Chemical compounds in the rempote Pacific troposphere: Comparison between MLOPEX measurements and chemical transport model calculations, J. Geophys. Res., 101, 14 795-14 813, 1996.

Brasseur, G. P., Hauglustaine, D. A., Walters, S., Rasch, P. J., and Müller, J.-F.: MOZART, a global chemical transport model for ozone and related chemical tracers, 1 . Model description, J. Geophys. Res., 103, 28 265-28 269, 1998.

Carter, W. P. L. and Atkinson, R.: Development and evaluation of a detailed mechanism for the atmospheric reactions of isoprene and $\mathrm{NO}_{\mathrm{x}}$, Int. J. Chem. Kinet., 28, 497-530, 1996.

Chatfield, R. B. and Crutzen, P. J.: Are there interactions of iodine and sulfur species in the marine air photochemistry?, J. Geophys. Res., 95, 22 319-22 341, 1990.

Chen, X., Hulbert, D., and Shepson, P. B.: Measurement of the organic nitrate yield from $\mathrm{OH}$ reaction with isoprene, J. Geophys. Res., 103, 25 563-25 568, 1998.

Collins, W. J., Stevenson, D. S., Johnson, C. E., and Derwent, R. G.: Role of convection in determining the budget of odd hydrogen in the upper troposphere, J. Geophys. Res., 104, 26927-26941, 1999.
Crutzen, P. J. and Lawrence, M. G.: The impact of precipitation scavenging on the transport of trace gases: A 3-dimensional model sensitivity study, J. Atmos. Chem., 37, 81-112, 2000.

Crutzen, P. J., Williams, J., Pöschl, U., Hoor, P., Fischer, H., Warneke, C., Holzinger, R., Hansel, A., Lindinger, W., Scheeren, B., and Lelieveld, J.: High spatial and temporal resolution measurements of primary organics and their oxidation products over the tropical forests of Surinam, Atmos. Environ., 34, 1161-1165, 2000.

Donoso, L., Romero, R., Rondon, A., Fernandez, E., Oyola, P., and Sanhueza, E.: Natural and anthropogenic $\mathrm{C}_{2}$ to $\mathrm{C}_{6}$ hydrocarbons in the central-eastern Venezuelan atmosphere during the rainy season, J. Atmos. Chem., 25, 201-214, 1996.

Galanter, M., Levy, H., and Carmichael, G. R.: Impacts of biomass burning on tropospheric $\mathrm{CO}, \mathrm{NO}_{\mathrm{x}}$, and $\mathrm{O}_{3}$, J. Geophys. Res., 105, 6633-6653, 2000.

Ganzeveld, L. and Lelieveld, J.: Dry deposition parameterization in a chemical general circulation model and its influence on the distribution of reactive trace gases, J. Geophys. Res., 100, 20999 $21012,1995$.

Ganzeveld, L. N., Lelieveld, J., Dentener, F. J., Krol, M. C., Bouwman, A. J., and Roelofs, G.-J.: Global soil-biogenic $\mathrm{NO}_{\mathrm{x}}$ emissions and the role of canopy processes, J. Geophys. Res., 107, 4298, doi:10.1029/2001JD001289, 2002.

Geiger, H., Barnes, I., Bejan, I., Benter, T., and Spittler, M.: The tropospheric degradation of isoprene: an updated module for the regional atmospheric chemistry mechanism, Atmos. Environ., 37, 1503-1519, 2003.

Gery, M. W., Whitten, G. Z., Killus, J. P., and Dodge, M. C.: A photochemical kinetics mechanism for urban and regional scale computer modeling, J. Geophys. Res., 94, 12 925-12 956, 1989.

Granier, C., Pétron, G., Müller, J.-F., and Brasseur, G.: The impact of natural and anthropogenic hydrocarbons on the tropospheric budget of carbon monoxide, Atmos. Environ., 34, 5255-5270, 2000 .

Greenberg, J. P. and Zimmerman, P. R.: Nonmethane hydrocarbons in remote tropical, continental, and marine atmospheres, J. Geophys. Res., 89, 4767-4778, 1984.

Guenther, A., Hewitt, C. N., Erickson, D., Fall, R., Geron, C., Graedel, T., Harley, P., Klinger, L., Lerdau, M., McKay, W. A., Pierce, T., Scholes, B., Steinbrecher, R., Tallamraju, R., Taylor, J., and Zimmerman, P.: A global model of natural volatile organic compound emissions, J. Geophys. Res., 100, 8873-8892, 1995.

Helmig, D., Balsley, B., Davis, K., Kuck, L. R., Jensen, M., Bognar, J., Jr., T. S., Arrieta, R. V., Rodriguez, R., and Birks, J. W.: Vertical profiling and determination of landscape fluxes of biogenic nonmethane hydrocarbons within the planetary boundary layer in the Peruvian Amazon, J. Geophys. Res., 103, 25 519-25 532, 1998.

Holzinger, R., Sanhueza, E., von Kuhlmann, R., Kleiss, B., Donoso, L., and Crutzen, P. J.: Diurnal cycles and seasonal variation of isoprene and its oxidation products in the tropical savanna atmosphere, Global Biogeochem. Cycles, 16, 1074, doi:10.1029/2001GB001421, 2002.

Houweling, S., Dentener, F., and Lelieveld, J.: The impact of nonmethane hydrocarbon compounds on tropospheric photochemistry, J. Geophys. Res., 103, $10673-10696,1998$.

Jacob, D. J. and Wofsy, S.: Budgets of reactive nitrogen, hydrocar- 
bons, and ozone over the Amazone forest during the wet season, J. Geophys. Res., 95, 16737-16754, 1990.

Jaeglé, L., Jacob, D. J., Wennberg, P. O., Spivakovsky, C. M., Hanisco, T. F., Lanzendorf, E. J., Hintsa, E. J., Fahey, D. W., Keim, E. R., Proffitt, M. H., Atlas, E. L., Flocke, F., Schauffler, S., McElroy, C. T., Midwinter, C., Pfister, L., and Wilson, J. C.: Observed $\mathrm{OH}$ and $\mathrm{HO}_{2}$ in the upper troposphere suggest a major source from convective injection of peroxides, Geophys. Res. Lett., 24, 3181-3184, 1997.

Jenkin, M., Saunders, S. M., and Pilling, M. J.: The tropospheric degradation of volatile organic compounds: A protocol for mechanism development, Atmos. Environ., 31, 81-104, 1997.

Jobson, B. T., Wu, Z., Niki, H., and Barrie, L. A.: Seasonal trends of isoprene, alkanes, and acetylene at a remote boreal site in Canada, J. Geophys. Res., 99, 1589-1599, 1994.

Kalnay, E., Kanamitsu, M., Kistler, R., Collins, W., Deaven, D., Gandin, L., Iredell, M., Saha, S., White, G., Woollen, J., Zhu, Y., Chelliah, M., Ebisuzaki, W., Higgins, W., Janowiak, J., Mo, K., Ropelewski, C., Wang, J., Leetmaa, A., Reynolds, R., Jenne, R., and Joseph, D.: The NCEP/NCAR 40-year reanalysis project, Bull. Am. Meteorol. Soc., 77, 437-471, 1996.

Kwok, E. S. C. and Atkinson, R.: Estimation of hydroxyl radical reaction rate constants for gas-phase organic compounds using a structure-reactivity relationship: an update, Atmos. Environ., 29, 1685-1695, 1995.

Lamb, B., Gay, D., Westberg, H., and Pierce, T.: A biogenic hydrocarbon emission inventory for the USA using a simple forest canopy model, Atmos. Environ., 27A, 1673-1690, 1993.

Lawrence, M. G., Chameides, W. L., Kasibhatla, P. S., Levy II, H., and Moxim, W.: Lightning and atmospheric chemistry: The rate of atmospheric NO production, vol. I, pp. 189-202, CRC Press, Inc., 1995.

Lawrence, M. G., Crutzen, P. J., Rasch, P. J., Eaton, B. E., and Mahowald, N. M.: A model for studies of tropospheric photochemistry: Description, global distributions, and evaluation, J. Geophys. Res., 104, 26 245-26 277, 1999.

Lawrence, M. G., Rasch, P. J., von Kuhlmann, R., Williams, J., Fischer, H., de Reus, M., Lelieveld, J., Crutzen, P. J., Schultz, M., Stier, P., Huntrieser, H., Heland, J., Stohl, A., Forster, C., Elbern, H., Jakobs, H., and Dickerson, R. R.: Global chemical weather forecasts for field campaign planning: predictions and observations of large-scale features during MINOS, CONTRACE, and INDOEX, Atmos. Chem. Phys., 3, 267-289, 2003.

Liang, J. and Jacobson, M. Z.: Comparison of a 4000-reaction chemical mechanism with the carbon bond IV and an adjusted carbon bond IV-EX mechanism using SMVGEAR II, Atmos. Environ., 34, 3015-3026, 2000.

Madronich, S. and Calvert, J. G.: The NCAR master mechanism of the gas phase chemistry - version 2.0, NCAR Technical Note 333+STR, National Center for Atmospheric Research, Boulder, Colorado, 1989.

Mahowald, N. M., Prinn, R. G., and Rasch, P. J.: Deducing $\mathrm{CCl}_{3} \mathrm{~F}$ emissions using an inverse method and chemical transport models with assimilated winds, J. Geophys. Res., 102, 28153 28 168, 1997a.

Mahowald, N. M., Rasch, P. J., Eaton, B. E., Whittlestone, S., and Prinn, R. G.: Transport of ${ }^{222}$ radon to the remote troposphere using the Model of Atmospheric Transport and Chemistry and assimilated winds from ECMWF and the National Center for En- vironmental Prediction/NCAR, J. Geophys. Res., 102, 28 13928 152, $1997 \mathrm{~b}$.

McKeen, S. A., Gierczak, T., Burkholder, J. B., Wennberg, P. O., Hanisco, T. F., Keim, E. R., Gao, R.-S., Liu, S. C., Ravishankara, A. R., and Fahey, D. W.: The photochemistry of acetone in the upper troposphere: A source of odd-hydrogen radicals, Geophys. Res. Lett., 24, 3177-3180, 1997.

Montzka, S. A., Trainer, M., Goldan, P. D., Kuster, W. C., and Fehsenfeld, F. C.: Isoprene and its oxidation products, methyl vinyl ketone and methacrolein, in the rural troposphere, J. Geophys. Res., 98, 1101-1111, 1993.

Müller, J.-F. and Brasseur, G.: IMAGES: A three-dimensional chemical transport model of the global troposphere, J. Geophys. Res., 100, 16445-16490, 1995.

Neeb, P.: Structure-reactivity based estimation of the rate constants for hydroxyl radical reactions with hydrocarbons, J. Atmos. Chem., 35, 295-315, 2000.

Olivier, J. G. J., Bouwman, A. F., van der Maas, C. W. M., Berdowski, J. J. M., Veldt, C., Bloos, J. P. J., Visschedijk, A. J. J., Zandveld, P. Y. J., and Haverlag, J. L.: Description of EDGAR version 2.0: A set of global inventories of greenhouse gases and ozone-depleting substances for all anthrophogenic and most natural sources on a per country $1^{\circ} \times 1^{\circ}$ grid, RIVM Rep. 771060002, Rijksinstituut, Bilthoven, Netherlands, 1996.

O'Sullivan, D. W., Lee, M., Noone, B. C., and Heikes, B. G.: Henry's law constant determinations for hydrogen peroxide, methyl hydroperoxide, hydroxymethyl hydroperoxide, ethyl hydroperoxide, and peroxyacetic acid, J. Phys. Chem., 100, 32413247, 1996.

Poisson, N.: Impact des hydrocarbures non méthaniques sur la chimie troposphérique, Ph.D. thesis, Université Paris, Paris, France, 1997.

Poisson, N., Kanakidou, M., and Crutzen, P. J.: Impact of nonmethane hydrocarbons on tropospheric chemistry and the oxidizing power of the global troposphere: 3-dimensional modelling results, J. Atmos. Chem., 36, 157-230, 2000.

Pöschl, U., von Kuhlmann, R., Poisson, N., and Crutzen, P. J.: Development and intercomparison of condensed isoprene oxidation mechanisms for global atmospheric modeling, J. Atmos. Chem., 37, 29-52, 2000.

Prather, M. J. and Jacob, D. J.: A persistent imbalance in $\mathrm{HO}_{\mathrm{x}}$ and $\mathrm{NO}_{\mathrm{x}}$ photochemistry of the upper troposphere driven by deep convection, Geophys. Res. Lett., 24, 3189-3192, 1997.

Price, C. and Rind, D.: Modeling global lightning distribution in a general circulation model, Mon. Weather Rev., 122, 1930-1939, 1994.

Rasch, P. J., Mahowald, N. M., and Eaton, B. E.: Representations of transport, convection and the hydrologic cycle in chemical transport models: Implications for the modeling of short lived and soluble species, J. Geophys. Res., 102, 28 127-28 138, 1997.

Rasmussen, R. A. and Khalil, M. A. K.: Isoprene over the Amazone basin, J. Geophys. Res., 93, 1417-1421, 1988.

Richter, A. and Burrows, J. P.: Tropospheric $\mathrm{NO}_{2}$ from GOME measurements, Adv. Space Res., 29, 1673-1683, 2002.

Rinne, H. J. I., Guenther, A. B., Greenberg, J. P., and Harley, P. C.: Isoprene and monoterpene fluxes measured above amazonian rainforest and their dependence on light and temperature, Atmos. Environ., 36, 2421-2426, 2002.

Roelofs, G.-J. and Lelieveld, J.: Tropospheric ozone simulation 
with a chemistry-general circulation model: Influence of higher hydrocarbon chemistry, J. Geophys. Res., 105, 22 697-22 712, 2000.

Rosenstiel, T. N., Potosnak, M. J., Griffin, K. L., Fall, R., and Monson, R. K.: Increased $\mathrm{CO}_{2}$ uncouples growth from isoprene emission in an agriforest ecosystem, Nature, 421 (6920), 256-259, 2003.

Sanderson, M. G., Jones, C. D., Collins, W. J., Johnson, C. E., and Derwent, R. G.: Effect of climate change on isoprene emissions and surface ozone levels, Geophys. Res. Lett., 30, 1936, doi:10.1029/2003GL017 642, 2003.

Saunders, S. M., Jenkin, M. E., Derwent, R. G., and Pilling, M. J.: World wide web site of a master chemical mechanism (MCM) for use in tropospheric chemistry models, Atmos. Environ., 31, 1249, http://www.chem.leeds.ac.uk/Atmospheric/ MCM/mcmproj.html 1997.

Shallcross, D. E. and Monks, P. S.: New directions: A role for isoprene in biosphere-climate-chemistry feedbacks, Atmos. Environ., 34, 1659-1660, 2000.

Shaw, R. W. J., Crittenden, A. L., Stevens, R. K., Cronn, D. R., and Titov, V. S.: Ambient concentrations of hydrocarbons from conifers in atmopsheric gases and aerosol particles measured in Soviet Georgia, Environ. Sci. Technol., 17, 389-395, 1983.

Singh, H. B., Herlth, D., O’Hara, D., Salas, L., Torres, A. L., Gregory, G. L., Sachse, G. W., and Kasting, J. F., Atmospheric peroxyacetyl nitrate measurements over the Brazilian amazon during the wet season: Relationships with nitrogen oxides and ozone, J. Geophys. Res., 95, 16 945-16954, 1990.

Sprengnether, M., Demerjian, K. L., Donahue, N. M., and Anderson, J. G.: Product analysis of the $\mathrm{OH}$ oxidation of isoprene and 1,3-butadiene in the presence of NO, J. Geophys. Res., 107, doi:10.1029/2001JD000716, 2002.

Torres, A. L. and Buchan, H.: Tropospheric nitric oxide measurements over the Amazon basin, J. Geophys. Res., 93, 1396-1406, 1988.

Treves, K., Shragina, L., and Rudich, Y.: Henry's law constants of some $\beta, \gamma$ and $\delta$ hydroxy alkyl nitrates of atmospheric interest, Env. Sci. Tech., 34, 1197-1203, 2000. von Kuhlmann, R.: Tropospheric Photochemistry of Ozone, its Precursors and the Hydroxyl Radical: A 3D-Modeling Study Considering Non-Methane Hydrocarbons, Ph.D. thesis, Johannes Gutenberg-Universität Mainz, Mainz, Germany, http://www. mpch-mainz.mpg.de/ $\sim$ kuhlmann, 2001.

von Kuhlmann, R., Lawrence, M. G., Crutzen, P. J., and Rasch, P. J.: A model for studies of tropospheric ozone and nonmethane hydrocarbons: Model description and ozone results, J. Geophys. Res., 108 (D9), 4294, doi:10.1029/2002JD002893, 2003a.

von Kuhlmann, R., Lawrence, M. G., Crutzen, P. J., and Rasch, P. J.: A model for studies of tropospheric ozone and non-methane hydrocarbons: Model evaluation of ozone related species, J. Geophys. Res., 108 (D23),4729, doi:10.1019/2002JD003348, 2003 b.

Wang, Y., Jacob, D. J., and Logan, J. A.: Global simulation of tropospheric $\mathrm{O}_{3}-\mathrm{NO}_{\mathrm{x}}$-hydrocarbon chemistry, 3. origin of tropospheric ozone and effects of non-methane hydrocarbons, J. Geophys. Res., 103, 10757-10767, 1998.

Warneke, C., Holzinger, R., Hansel, A., Jordan, A., Lindinger, W. Pöschl, U., Williams, J., Hoor, P., Fischer, H., Crutzen, P. J., Scheeren, H. A., and Lelieveld, J.: Isoprene and its oxidation products methyl vinyl ketone, methacrolein, and isoprene related peroxides measured online over the tropical rain forest of Surinam in March 1998, J. Atmos. Chem., 38, 167-185, 2001.

Wesely, M. L.: Parameterization of surface resistances to gaseous dry deposition in regional-scale numerical models, Atmos. Environ., 23, 1293-1304, 1989.

Yienger, J. J. and Levy, H.: Empirical model of global soil-biogenic $\mathrm{NO}_{\mathrm{X}}$ emissions, J. Geophys. Res., 100, 11 447-11 464, 1995.

Yokouchi, Y.: Seasonal and diurnal variation of isoprene and its reaction products in a semi-rural area, Atmos. Environ., 28, 26512658, 1994.

Zaveri, R. A. and Peters, L. K.: A new lumped structure photochemical mechanism for large-scale applications, J. Geophys. Res., 104, 30 387-30 415, 1999.

Zimmerman, P. R., Greenberg, J. P., and Westberg, C. E.: Measurements of atmospheric hydrocarbons and biogenic emission fluxes in the Amazon boundary layer, J. Geophys. Res., 93, 1407-1416, 1988. 